University of Vermont

UVM ScholarWorks

Rubenstein School of Environment and Natural Rubenstein School of Environment and Natural Resources Faculty Publications

$11-1-2012$

\title{
Shedding light on plant litter decomposition: Advances, implications and new directions in understanding the role of photodegradation
}

\author{
Jennifer Y. King \\ University of California, Santa Barbara \\ Leslie A. Brandt \\ USDA Forest Service \\ E. Carol Adair \\ National Center for Ecological Analysis and Synthesis
}

Follow this and additional works at: https://scholarworks.uvm.edu/rsfac

Part of the Climate Commons

\section{Recommended Citation}

King JY, Brandt LA, Adair EC. Shedding light on plant litter decomposition: advances, implications and new directions in understanding the role of photodegradation. Biogeochemistry. 2012 Nov;111(1):57-81.

This Article is brought to you for free and open access by the Rubenstein School of Environment and Natural Resources at UVM ScholarWorks. It has been accepted for inclusion in Rubenstein School of Environment and Natural Resources Faculty Publications by an authorized administrator of UVM ScholarWorks. For more information, please contact scholarworks@uvm.edu. 


\title{
Shedding light on plant litter decomposition: advances, implications and new directions in understanding the role of photodegradation
}

\author{
Jennifer Y. King • Leslie A. Brandt • \\ E. Carol Adair
}

Received: 15 December 2011/Accepted: 12 April 2012/Published online: 10 June 2012

(C) US Government 2012

\begin{abstract}
Litter decomposition contributes to one of the largest fluxes of carbon (C) in the terrestrial biosphere and is a primary control on nutrient cycling. The inability of models using climate and litter chemistry to predict decomposition in dry environments has stimulated investigation of non-traditional drivers of decomposition, including photodegradation, the abiotic decomposition of organic matter via exposure to solar radiation. Recent work in this
\end{abstract}

Author contributions All authors contributed equally to the manuscript and revisions.

J. Y. King $(\bowtie)$

Department of Geography, University of California, Santa Barbara, CA 93106-4060, USA

e-mail: jyking@geog.ucsb.edu

L. A. Brandt

Northern Institute of Applied Climate Science, USDA Forest Service, Saint Paul, MN 55108, USA

e-mail: lbrandt@fs.fed.us

E. C. Adair

National Center for Ecological Analysis and Synthesis

(NCEAS), University of California, Santa Barbara,

CA 93101, USA

e-mail: Carol.Adair@uvm.edu

Present Address:

E. C. Adair

Rubenstein School of Environment and Natural

Resources, University of Vermont, Burlington,

VT 05405, USA developing field shows that photodegradation may substantially influence terrestrial $\mathrm{C}$ fluxes, including abiotic production of carbon dioxide, carbon monoxide and methane, especially in arid and semi-arid regions. Research has also produced contradictory results regarding controls on photodegradation. Here we summarize the state of knowledge about the role of photodegradation in litter decomposition and $\mathrm{C}$ cycling and investigate drivers of photodegradation across experiments using a meta-analysis. Overall, increasing litter exposure to solar radiation increased mass loss by $23 \%$ with large variation in photodegradation rates among and within ecosystems. This variation was tied to both litter and environmental characteristics. Photodegradation increased with litter $\mathrm{C}$ to nitrogen $(\mathrm{N})$ ratio, but not with lignin content, suggesting that we do not yet fully understand the underlying mechanisms. Photodegradation also increased with factors that increased solar radiation exposure (latitude and litter area to mass ratio) and decreased with mean annual precipitation. The impact of photodegradation on $\mathrm{C}$ (and potentially $\mathrm{N}$ ) cycling fundamentally reshapes our thinking of decomposition as a solely biological process and requires that we define the mechanisms driving photodegradation before we can accurately represent photodegradation in global $\mathrm{C}$ and $\mathrm{N}$ models.

Keywords UV-B - Solar radiation · Arid ecosystems · Grasslands · Carbon · Nitrogen · Lignin 


\section{Introduction}

Ecosystem carbon (C) and nutrient cycling is driven by the two fundamental processes of production and decomposition. In terrestrial ecosystems, the physical and biological controls on ecosystem productivity are relatively well known and can be accurately modeled (Cramer et al. 1999), but researchers have had less success modeling decomposition rates across space and time, especially of leaf litter on the soil surface (Whitford et al. 1981; Moorhead et al. 1999; Gholz et al. 2000; Adair et al. 2008). Work over the last 5 years suggests that an abiotic process, photodegradation, may help to explain some of the problems in modeling decomposition to date (e.g. Parton et al. 2007).

Photodegradation, the breakdown of organic matter via solar radiation, can increase decomposition rates and lead to changes in the way $\mathrm{C}$ and nutrients are cycled among plants, soil and atmosphere. There are several paths by which solar radiation has been observed to influence pools and fluxes associated with plant litter decomposition (Fig. 1). Solar radiation may increase decomposition fluxes from soil organic matter (SOM) and litter via abiotic photochemical reactions or facilitation of microbial decomposition through the production of labile photodegraded material (e.g. Austin and Vivanco 2006; Brandt et al. 2009; Foereid et al. 2010). However solar radiation can also have negative effects on fluxes through direct negative impacts on microbial and plant growth (e.g. Johanson et al. 1995; Duguay and Klironomos 2000; Johnson 2003; Belnap et al. 2008). Thus, solar radiation may decrease pool sizes by suppressing plant growth and associated inputs or by increasing outputs from litter, soil and dissolved organic matter (DOM; via photodegradation/facilitation of decomposition). Solar radiation may increase or decrease the recalcitrance and microbial uptake of DOM depending on the source of DOM (Moran and Zepp 1997). $\mathrm{CO}_{2}$ fluxes from microbial respiration can be positive or negative depending on whether solar radiation has a net positive effect by increasing labile carbon or a net negative effect by reducing microbial growth (e.g. Foereid et al. 2010; Johnson 2003).

Given the complexity of solar radiation effects on decomposition, an increased understanding of the underlying mechanisms is critically needed. Here, we summarize recent advances in understanding the role of photodegradation in plant litter decomposition in three main areas: (1) the mechanisms by which litter is photodegraded; (2) the role photodegradation plays in
Fig. 1 Observed effects of solar radiation on pools and fluxes of decomposition. A negative effect on pool size indicates that outputs exceed inputs. For litter and microbial biomass, this is a consequence of negative effects of UV radiation on growth. For soil and dissolved organic matter, this is a consequence of increased fluxes from the pool without an increase in inputs. Extracellular enzymes are included in the microbial biomass pool. Please refer to text for further discussion

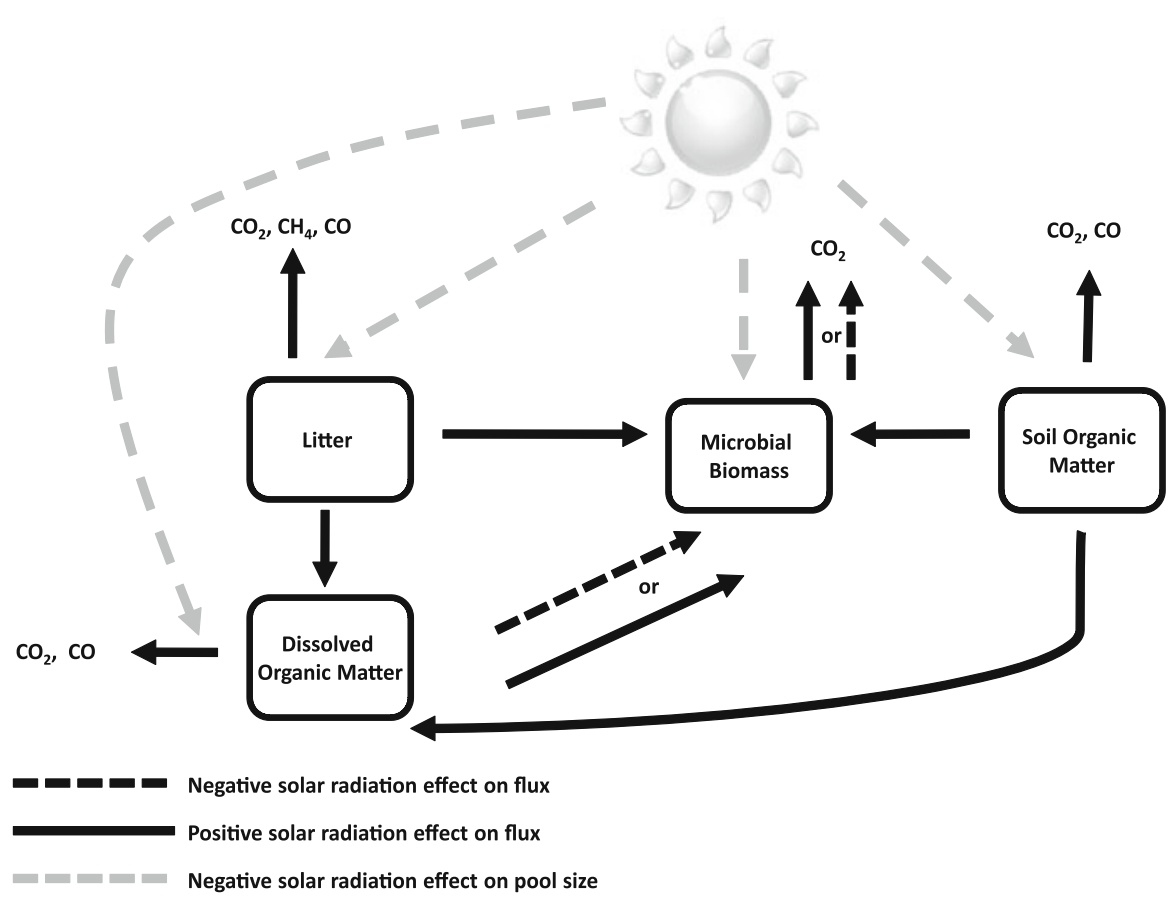


the global carbon cycle; and (3) the factors that influence the role of photodegradation in litter mass loss across all field experiments to date using a metaanalysis. We then explore implications for modeling biogeochemical processes. Finally, we provide recommendations for future research needed to fill critical gaps in the understanding of this important process.

\section{Historical context}

Research on decomposition has shown that litter in arid ecosystems decomposes faster than predicted by microbial drivers, namely climate and litter chemistry (Whitford et al. 1981; Adair et al. 2008; Austin 2011). Several hypotheses for this phenomenon have been proposed, such as litter consumption by termites (Johnson and Whitford 1975; Whitford et al. 1982). Pauli (1964) first proposed that solar radiation may play a role in driving decomposition in arid ecosystems, and although the idea was reiterated two decades later (Moorhead and Reynolds 1989), the hypothesis went largely untested with a few exceptions (Zlotin 1979; Mackay et al. 1994).

Recognition of the impacts of chlorofluorocarbons on stratospheric ozone in the 1980s led to research on the impacts of increased ultraviolet-B radiation (UV-BR) on decomposition and nutrient cycling (related to the most recent United Nations Environment Programme (UNEP) Environmental Effects Assessment Panel (EEAP) Report, see Ballaré et al. 2011 and Zepp et al. 2011 and references therein). These studies focused primarily on decomposition in high latitude systems where ozone depletion is greatest (Gehrke et al. 1995; Johanson et al. 1995; Paul et al. 1999). Many of these studies indicated that the primary mechanisms of UV-BR impacts on decomposition were indirect, mediated through changes in litter chemistry or changes in soil biota, rather than the direct result of incident UV-BR inducing litter mass loss (reviewed in Paul et al. 1999). These studies provided important advances in methodology for manipulating solar radiation at different wavelengths and introduced the concept of photodegradation to a larger audience in the terrestrial ecology field.

Research on the contribution of plants and litter to atmospheric trace gas concentrations became a topic of interest in the 1990s and remains so today. Work in the 1990s on carbon monoxide (CO) emissions showed that solar radiation plays a large role in $\mathrm{CO}$ emissions from plant litter and SOM (Tarr et al. 1995; Schade et al. 1999; Kisselle et al. 2002). However, the role of solar radiation in the production of other trace gases from plants, litter and soil remained largely ignored until the past 5 years. One exception was work by Anesio et al. (1999), showing that carbon dioxide $\left(\mathrm{CO}_{2}\right)$ could also be produced by photodegradation.

In contrast to terrestrial systems, work in the $1990 \mathrm{~s}$ on biogeochemical cycling in aquatic systems significantly advanced understanding of photodegradation's role in decomposing DOM. The large body of work in marine and freshwater systems indicates that photochemical reactions with DOM produce an additional $1 \mathrm{Gt} \mathrm{C}$ year $^{-1}$ and $15 \mathrm{Mt}$ nitrogen (N) year ${ }^{-1}$ for heterotrophic utilization and convert 12-16 Gt C year ${ }^{-1}$ to $\mathrm{CO}_{2}$ through direct photochemical reactions (Moran and Zepp 1997). Research on DOM continues to explore variation among and within systems in photodegradation rates (e.g., with changes in salinity, DOM source and temperature) and interactions with microbial utilization (Obernosterer and Benner 2004; Anesio et al. 2005; Amado et al. 2007; Nelson et al. 2010). Recent work has focused on identifying underlying mechanisms of DOM photochemical reactions (Boreen et al. 2008; Cory et al. 2010; Vione et al. 2010). Other studies have examined photodegradation of submerged or emergent aquatic vegetation, providing a link between terrestrial litter decomposition and aquatic systems (Denward and Tranvik 1998; Vahatalo et al. 1998; Anesio et al. 1999; Denward et al. 2001; Hernes and Benner 2003).

As questions remained about the relatively high rates of litter decomposition in arid ecosystems, terrestrial ecologists, informed by the findings and methods from aquatic systems, began to investigate the potential importance of photodegradation.

\section{Mechanisms}

How does exposure to solar radiation degrade terrestrial litter and soil? The mechanisms involved, and whether they are similar to those discovered in the fields of aquatic biochemistry, materials science and atmospheric chemistry, remain relatively unknown. Here we discuss our current understanding of the mechanisms underlying litter mass loss through 
photodegradation, as well as possible mechanisms gleaned from work in other fields.

\section{Wavelength}

It was originally hypothesized that wavelengths in the UV-B range (280-320 nm) were responsible for photodegradation, but sufficient evidence suggests that other wavelengths, particularly those in the UV-A range (320-400 $\mathrm{nm}$ ) and the short-wave visible range $(400-500 \mathrm{~nm})$, play an equal if not greater role (Austin and Vivanco 2006; Brandt et al. 2009; Austin and Ballaré 2010). Many plant compounds have a maximum absorbance in the UV-B range, but they also absorb lesser amounts of radiation at other wavelengths. Since the atmosphere absorbs much of the UV-BR before it hits Earth's surface, visible and, to a lesser extent, UV-A radiation make up a much larger proportion of the photon flux to the litter layer. Therefore, litter photodegradation rates may be higher on a per photon basis in the UV-B range, but lower in total compared to longer wavelengths. Such hypotheses have yet to be tested (Fig. 2, "Mechanistic research"), but recent work has pushed forward our understanding of terrestrial photodegradation by expanding the definition of photo-active radiation to include shortwave visible wavelengths.
Photoreactive compounds

It has long been assumed that lignin is the primary compound in litter susceptible to photodegradation, but there has been relatively little evidence to support this assumption. Studies that have measured changes in litter chemistry over time under different radiation treatments have typically found only small treatment effects on either lignin or other compounds such as cellulose (Rozema et al. 1997; Brandt et al. 2007, 2010; Day et al. 2007). However, a recent study by Austin and Ballaré (2010) showed that photodegradation did not occur when lignin-free, pure cellulose substrates were exposed to radiation but did occur when a lignin solution was added to the substrates. Furthermore, rates of photodegradation increased with solution lignin concentration, and mass loss patterns were consistent with what would be predicted if only lignin were lost in this process. This study shows that lignin is at least one of the photoreactive compounds and that cellulose (in a highly purified form) does not appear capable of absorbing radiation and photodegrading in isolation. This study only tested two highly purified forms of lignin and cellulose. Results could vary with plant species differences in lignin structure and chemistry and the extent of decomposition that has already occurred. Lignin in the lignocellulose matrix
Fig. 2 Recommended future research directions to advance understanding of the role of photodegradation

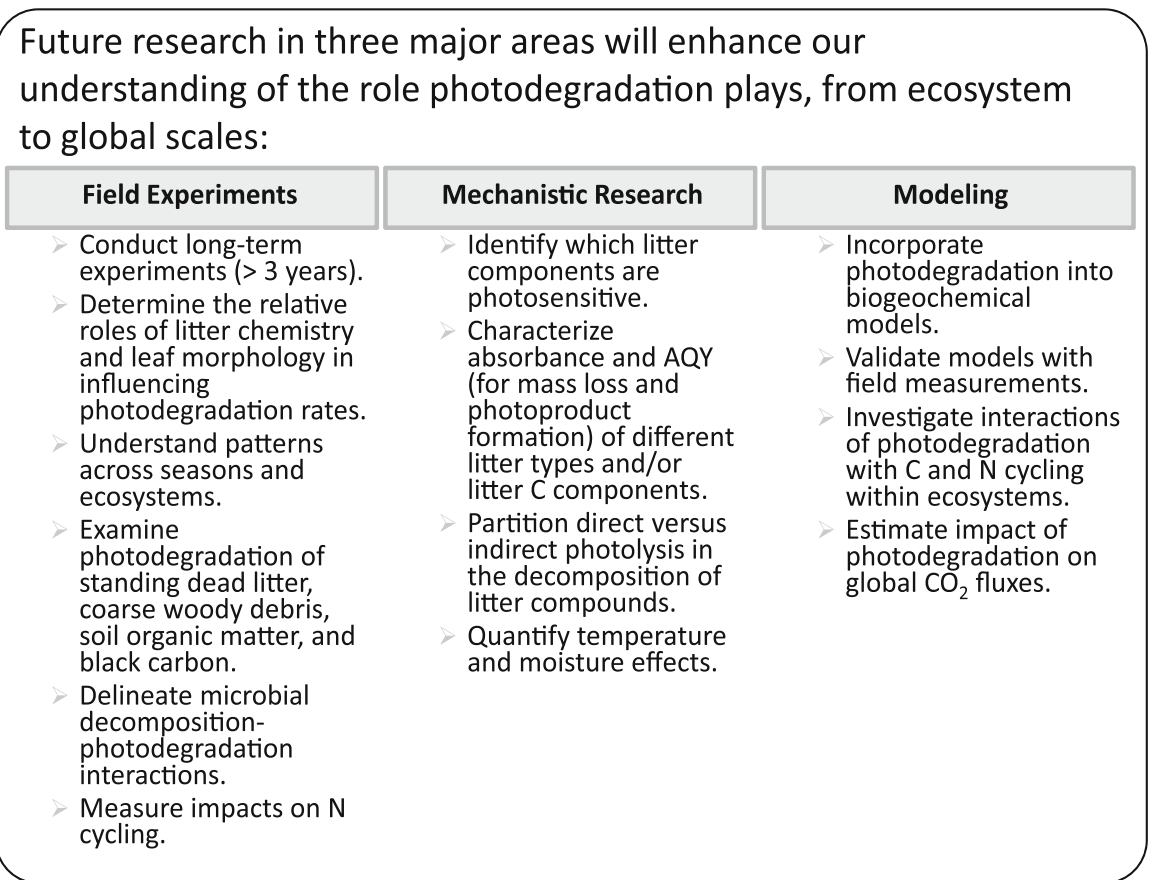


of plant tissue may have a different susceptibility to photodegradation than purified lignin. It is also possible that compounds not examined in this study could be photoreactive, including proteins and other phenolics besides lignin (see Fig. 3).

\section{Direct and indirect photolysis}

The chemical mechanisms behind litter photodegradation remain unknown, but general principles of photochemistry along with evidence from other fields can provide a good starting point. When a molecule absorbs radiation and it results in a permanent change to the molecule, such as fragmentation, intramolecular rearrangement or electron transfer from or to the molecule, it is generally referred to as "direct photolysis" (Fig. 3). For example, a lignin molecule could undergo fragmentation into smaller organic components, which then could be consumed by microbes or leached out of the litter layer. This fragmentation could also result in the formation of inorganic $\mathrm{C}$ compounds such as $\mathrm{CO}$ or $\mathrm{CO}_{2}$. Research on photodegradation of DOM in aquatic systems has shown that direct photolysis does occur to some extent (Kieber et al. 1999). This mechanism may be a factor in studies that have shown a decrease in litter lignin content when exposed to solar radiation (Rozema et al.
1997; Day et al. 2007; Henry et al. 2008; Austin and Ballaré 2010).

In addition to direct photolysis, "indirect photolysis" may also play a role in the decomposition of organic substrates (Fig. 3; see also review by Lanzalunga and Bietti 2000). During indirect photolysis, photosensitizers absorb radiation and transfer energy to other molecules (often triplet oxygen), creating reactive intermediates such as singlet oxygen, hydroxyl radical or hydrogen peroxide. Other important reactive intermediates can include reduced iron, copper or manganese. Reactive intermediates then change the chemistry of another non-light-absorbing molecule or part of the same molecule where the photosensitizer resided. In the case of litter photodegradation, light-absorbing (chromophoric) structures in lignin or molecules in litter may act as photosensitizers, facilitating chemical transformations of compounds that do not absorb much radiation, such as nonchromophoric lignin components, cellulose or hemicellulose. Research in aquatic systems and on wood and paper materials has shown that indirect photochemical processes are the primary mechanisms by which many organic materials are photodegraded (reviewed in George et al. 2005; Cory et al. 2010). In addition, recent studies have shown that photosensitized production of reactive oxygen species is the
Fig. 3 Illustration of direct and indirect photolysis pathways for the breakdown of organic compounds in litter. Direct photolysis breaks bonds in litter compounds and leads directly to the formation of new products. Indirect photolysis occurs when a photosensitive compound creates a reactive intermediate that goes on to react with compounds in the litter and form new products. "Imw" refers to low molecular weight; lignin* refers to organic reactive intermediates including lignin

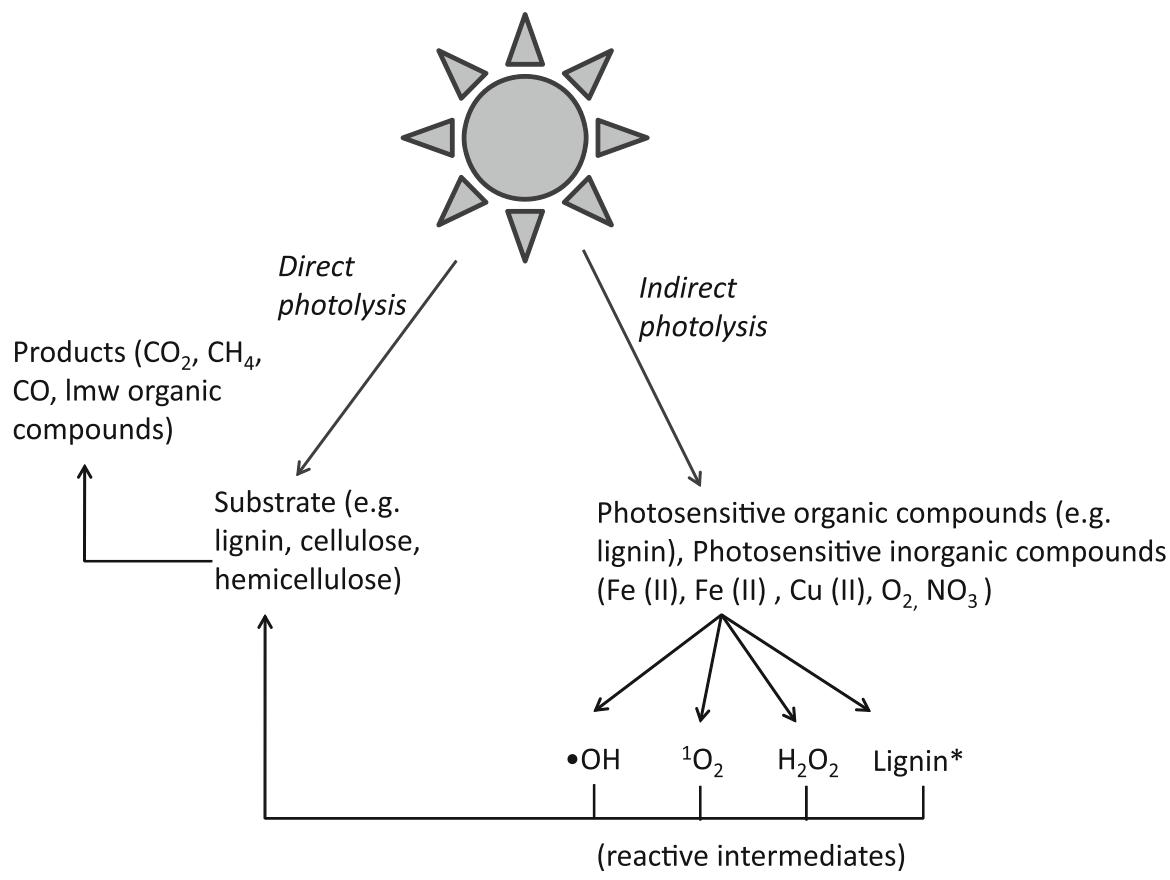


primary mechanism for photochemical production of $\mathrm{CH}_{4}$ from plant pectins (McLeod et al. 2008, Messenger et al. 2009). This mechanism could explain why some studies have seen decreases in cellulose but not lignin when litter is exposed solar radiation (Brandt et al. 2007, 2010). Indirect photolysis could be an alternative mechanism for observed lignin loss (Rozema et al. 1997; Day et al. 2007; Henry et al. 2008; Austin and Ballaré 2010). In addition, direct photolysis may also result in the production of reactive intermediates that can facilitate indirect photolysis (Lanzalunga and Bietti 2000).

\section{Interactions with other decomposition processes}

Modifications to litter by direct or indirect photochemical processes can lead to modifications in other decomposition processes, including the biodegradability of litter. A recent study showed that preexposure of litter to solar radiation can make it more digestible when subsequently decomposed under conditions favoring microbial decomposition (Foereid et al. 2010). Another recent study suggests that the radiation exposure conditions for plant litter may affect the size of respiration pulses of $\mathrm{CO}_{2}$ emissions during subsequent precipitation events (Ma et al. 2012). The facilitation of microbial decomposition by photodegradation appears to depend heavily on length of exposure, and studies exposing litter for short periods of time (e.g. a season) do not show the same effects as those conducted over longer time periods (Brandt et al. 2009; Foereid et al. 2010; Kirschbaum et al. 2011). However, studies in the aquatic literature have shown that photodegradation effects on subsequent microbial decomposition can also be negative, depending on the chemistry of organic materials being bio-and photo-degraded (Tranvik and Bertilsson 2001). Since relatively few studies have examined this interaction, it is too early to generalize about the magnitude or direction of this interaction.

Photodegradation can also interact with other physical decomposition processes. It can increase the solubility of litter, leading to increased leaching (Gallo et al. 2006; Feng et al. 2011). Research by Feng et al. (2011) suggests that this effect may be dependent on litter type, as increases in water-extractable organic $\mathrm{C}$ from photodegradation were seen for pine but not maize litter. This may explain why a study examining grass and oak litters found no effect of UV-radiation exposure on DOC leached from litter (Brandt et al. 2009), while another study examining conifer litter reported a significant increase (Gallo et al. 2006). In addition to leaching, physical processes common in arid, light-exposed systems such as wind or soil abrasion could interact with photodegradation, but this interaction remains relatively unstudied (Throop and Archer 2007; Austin 2011). One recent study suggests that freeze-thaw cycles in colder climates may contribute to accelerated mass loss by photodegradation (Uselman et al. 2011).

\section{Influence on the global carbon cycle}

The effects of ozone depletion and climate change on ultraviolet radiation are expected to have measurable impacts on the global C cycle (Zepp et al. 2011), but the specific contributions of photodegradation are not well known. The factors that affect solar radiation exposure and, therefore, photodegradation, are highly complex, varying considerably with ecosystem type, as well as through space and time (Table 1). Foereid et al. (2011) estimated of the importance of photodegradation to overall litter decomposition on a global scale by comparing modeled global photodegradation fluxes, based on experimental data from three sites, against ecosystem NPP. Their modeled estimates suggest that only $0.5-1.6 \%$ of global NPP is photodegraded. However, in dry, light-exposed ecosystems, up to $14 \%$ of NPP can be lost via photodegradation (Foereid et al. 2011). It appears that the primary influence of photodegradation on the $\mathrm{C}$ cycle is to accelerate return of $\mathrm{C}$ to the atmosphere. Welldocumented pathways of $\mathrm{C}$ return to the atmosphere are the direct abiotic losses of $\mathrm{CO}_{2}$ (Anesio et al. 1999; Brandt et al. 2009; Rutledge et al. 2010), CO (Tarr et al. 1995; Schade et al. 1999; Kisselle et al. 2002; Derendorp et al. 2011b), methane $\left(\mathrm{CH}_{4}\right.$, McLeod et al. 2008; Vigano et al. 2008; Bruhn et al. 2009; Messenger et al. 2009) and trace amounts of ethane and ethylene and other hydrocarbons (McLeod et al. 2008; Derendorp et al. 2011a; Table 2).

The first estimates of photochemical $\mathrm{CO}_{2}$ emissions were based on exposure of dry aquatic macrophyte litter to only UV radiation in the laboratory (0.0108 $\mathrm{g} \mathrm{C} \mathrm{m}^{-2}$ day $^{-1}$; Anesio et al. 1999). In comparison, measurements made in microcosms under natural solar radiation on clear sunny days in summer resulted 
Table 1 Factors affecting solar radiation exposure and subsequent photodegradation from global to plot-level scales

\begin{tabular}{|c|c|c|}
\hline Factor & Potential influence & References \\
\hline Ozone & $\begin{array}{l}\text { Possible slight increase with stratospheric ozone thinning. } \\
\text { Potential decreases with high tropospheric ozone. }\end{array}$ & Smith et al. (2010) \\
\hline Latitude & $\begin{array}{l}\text { Generally negative relationship. } \\
\text { High latitudes susceptible during summer months due } \\
\text { to ozone thinning. }\end{array}$ & $\begin{array}{l}\text { Moody et al. (2001), } \\
\text { Pancotto et al. (2003), } \\
\text { Brandt et al. (2010) }\end{array}$ \\
\hline Season & $\begin{array}{l}\text { In grasslands, highest rates during summer in grasslands if } \\
\text { seasonally dry, but rates may be higher in spring in areas with } \\
\text { summer monsoons. } \\
\text { In temperate deciduous forests, highest directly before leafout } \\
\text { in spring or after senescence in autumn. } \\
\text { In tropical deciduous forests, highest during dry season. }\end{array}$ & $\begin{array}{l}\text { Henry et al. (2008), } \\
\text { Brandt et al. (2010), } \\
\text { Rutledge et al. (2010) }\end{array}$ \\
\hline Elevation & $\begin{array}{l}\text { Most likely positive relationship due to higher proportion of } \\
\text { short-wave radiation and higher total irradiance at high } \\
\text { elevations. } \\
\text { May be negative relationship in areas where cloud, canopy, or } \\
\text { snow cover increases with elevation to the point where litter } \\
\text { is shaded. }\end{array}$ & Blumthaler et al. (1997) \\
\hline Cloud cover & $\begin{array}{l}\text { Most likely negative relationship. } \\
\text { Modest cloud cover can increase diffuse radiation and } \\
\text { potentially increase rates on mostly sunny days }\end{array}$ & Madronich et al. (1998) \\
\hline Leaf area index & $\begin{array}{l}\text { Generally negative relationship, but especially so with } \\
\text { broadleaf architecture. }\end{array}$ & Rozema et al. (1999) \\
\hline Canopy architecture & $\begin{array}{l}\text { Higher rates with vertically-distributed structure (e.g. } \\
\text { grasslands) than horizontally-distributed structure (e.g. } \\
\text { broadleaf forests). }\end{array}$ & Rozema et al. (1999) \\
\hline Landscape patchiness/ & Higher rates in open areas versus under shrubs or trees. & Köchy and Wilson (1997): \\
\hline evenness & $\begin{array}{l}\text { Rates per unit mass potentially greater with increased } \\
\text { evenness. }\end{array}$ & $\begin{array}{l}\text { Throop and Archer (2007), } \\
\text { Mlambo and Mwenje (2010) }\end{array}$ \\
\hline Soil reflectivity & $\begin{array}{l}\text { Sandy soils may increase albedo and lead to increased rates } \\
\text { in adjacent litter. }\end{array}$ & Rozema et al. (1999) \\
\hline Snow & $\begin{array}{l}\text { No photodegradation when buried. } \\
\text { Potential increase in photodegradation in standing dead if } \\
\text { surrounded by snow due to albedo. }\end{array}$ & $\mathrm{N} / \mathrm{A}^{\mathrm{a}}$ \\
\hline Litter position/location & $\begin{array}{l}\text { Standing dead litter may be more susceptible than litter } \\
\text { positioned flat on the ground. }\end{array}$ & $\mathrm{N} / \mathrm{A}^{\mathrm{a}}$ \\
\hline Litter layer thickness & $\begin{array}{l}\text { Rates per unit mass of litter higher with lower litter layer } \\
\text { thickness. }\end{array}$ & $\begin{array}{l}\text { Henry et al. (2008), } \\
\text { Brandt et al. (2009) }\end{array}$ \\
\hline Soil cover/burial & Decreased rates with increasing soil burial. & $\begin{array}{l}\text { Throop and Archer (2007), } \\
\text { Brandt et al. (2010) } \\
\text { Barnes et al. (2012) }\end{array}$ \\
\hline
\end{tabular}

${ }^{\text {a }}$ N/A no current publications on this topic

in slightly higher estimates $\left(0.016 \mathrm{~g} \mathrm{C} \mathrm{m}^{-2}\right.$ day $\left.^{-1}\right)$ and showed that other wavelengths play a role in litter photodegradation (Brandt et al. 2009). Rutledge et al. (2010) estimated photodegradation $\mathrm{CO}_{2}$ emissions based on eddy covariance and clear chamber measurements during daylight and non-daylight hours.
Their estimates $\left(0.186 \mathrm{~g} \mathrm{C} \mathrm{m}^{-2}\right.$ day $^{-1}$ in annual grasslands during the dry season and 0.093$0.18 \mathrm{~g} \mathrm{C} \mathrm{m}^{-2}$ day $^{-1}$ in harvested peatlands) are much higher than the laboratory and microcosm measurements described above. Such contrasting estimates make it clear that a better understanding of how and 
Table 2 Trace gas emissions from photodegrading plant materials

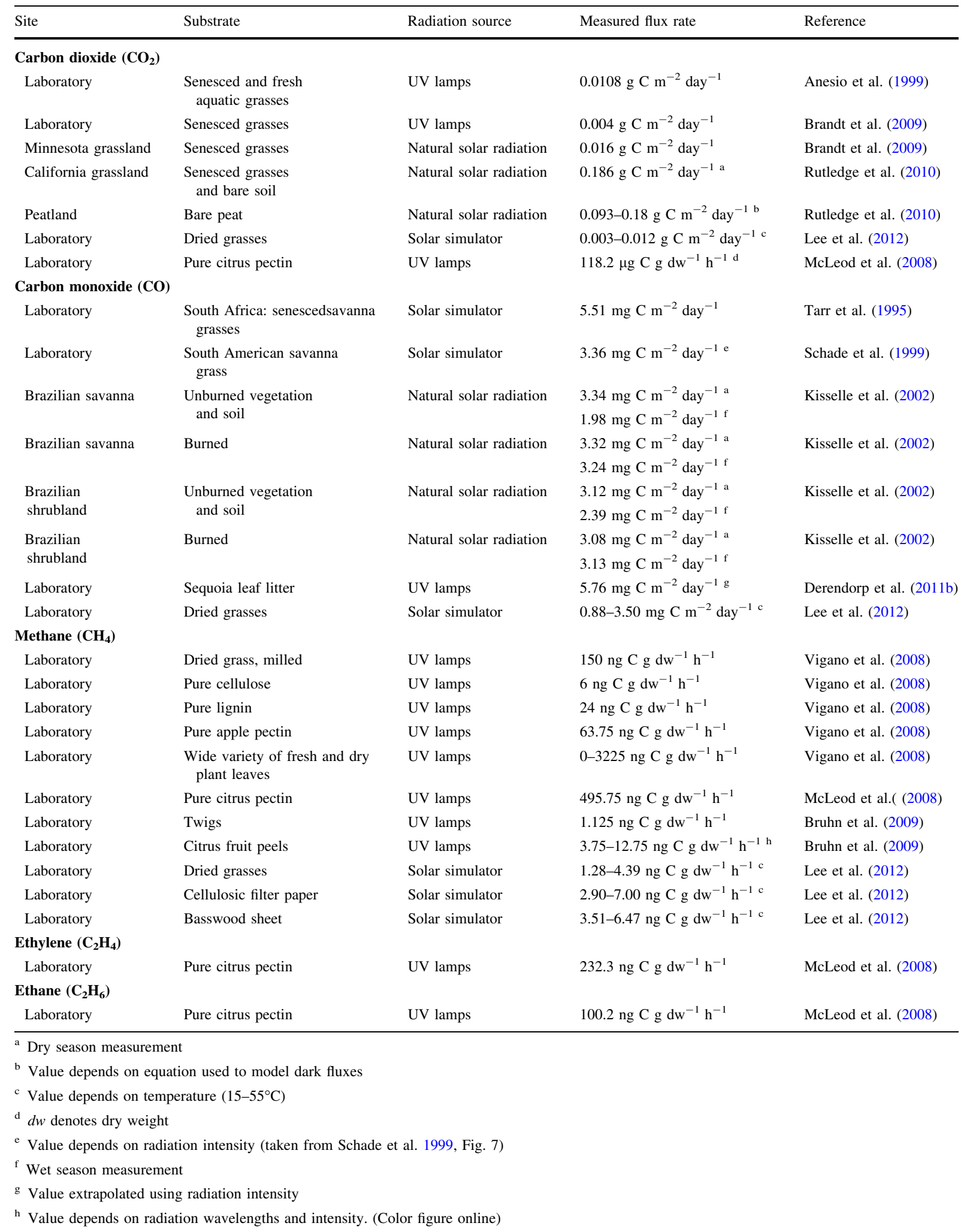


why rates of photochemical $\mathrm{CO}_{2}$ production vary across ecosystems (e.g., variation in radiation exposure; Table 1) is needed before we can make accurate estimates of its contribution to global $\mathrm{CO}_{2}$ emissions.

Measured rates of photochemical $\mathrm{CO}$ production from litter under natural or simulated solar radiation conditions generally range from approximately 2-5.5 $\mathrm{mg} \mathrm{C} \mathrm{m}^{-2}$ day $^{-1}$ (Tarr et al. 1995; Schade et al. 1999; Kisselle et al. 2002; Table 2). Using response factors developed for $\mathrm{CO}$ emissions together with global land area and irradiance datasets, Schade and Crutzen (1999) estimated the global source strength of $\mathrm{CO}$ emissions from photodegradation to be on the order of $100 \mathrm{Tg} \mathrm{CO}$ year $^{-1}$. Schade et al. (1999) also measured thermal emissions of CO, but those emissions were lower, by as much as an order of magnitude, than photochemical emissions. In a recent study, Lee et al. (2012) documented the production of $\mathrm{CO}$, as well as $\mathrm{CO}_{2}$ and $\mathrm{CH}_{4}$, through photodegradation and thermal processes. Their controlled laboratory study of six different plant materials showed that higher production of trace gases occurred during photodegradation compared to thermal degradation and that photodegradation production rates varied depending on temperature. The molar ratio of thermal degradation to photodegradation for $\mathrm{CO}$ ranged from 0.07 to 0.28 (for temperatures from 25 to $55^{\circ} \mathrm{C}$; Lee et al. 2012). This result is similar to the findings of Schade et al. (1999). Consistent with our summary of trace gas production in separate studies (Table 2), Lee et al. found, using simultaneous measurements of these trace gases, that the primary trace gas produced during both photodegradation and thermal degradation is $\mathrm{CO}_{2}$ (Lee et al. 2012).

The magnitude of photochemical $\mathrm{CH}_{4}$ fluxes varies depending on experimental conditions and on materials exposed (Table 2; values in Table 2 converted to ng $\mathrm{C} \mathrm{g}$ dry weight ${ }^{-1} \mathrm{~h}^{-1}$ for comparison). Most studies to date have focused on a limited set of plant materials (tobacco leaves, citrus pectin) or plant structural compounds (lignin, pectin, but see Lee et al. 2012). McLeod et al. (2008) reported $\mathrm{CH}_{4}$ emissions of up to $661 \mathrm{ng} \mathrm{CH}$ g dry weight ${ }^{-1} \mathrm{~h}^{-1}$ for citrus pectin, while Bruhn et al. (2009) reported emissions that ranged from 5 to $17 \mathrm{ng} \mathrm{CH}_{4}$ g dry weight $^{-1} \mathrm{~h}^{-1}$ for similar material. The widest range of materials studied is reported by Vigano et al. (2008) in which the range of $\mathrm{CH}_{4}$ emissions was also wide (0-4300 ng $\mathrm{CH}_{4}$ g dry weight ${ }^{-1} \mathrm{~h}^{-1}$ ). Bloom et al.
(2010) used an approach similar to Schade and Crutzen (1999) to estimate global $\mathrm{CH}_{4}$ emissions derived from photodegradation of foliar pectin. Their estimate, 0.2-1.0 $\mathrm{Tg} \mathrm{CH}_{4}$ year $^{-1}$, is small compared to other estimates of foliar $\mathrm{CH}_{4}$ emissions (1-7 Tg $\mathrm{CH}_{4}$ yesr $^{-1}$, Keppler et al. 2006) and points to the need for further mechanistic studies (Fig. 2).

Little is known about the influence of photodegradation on other biogeochemical cycles, such as nitrogen $(\mathrm{N})$. Because photodegradation is an abiotic process, litter that is low in $\mathrm{N}$ and is primarily decomposed by photodegradation should not have the same immobilization and mineralization patterns that are often observed in systems controlled by microbial decomposition (Parton et al. 2007). Two studies have found partial support for this hypothesis (Brandt et al. 2007; Smith et al. 2010). In addition, a study by McCalley and Sparks (2009) showed that soil exposed to solar radiation releases trace $\mathrm{N}$ gases at higher rates than when kept under dark conditions, and Mayer et al. (2012) recently reported $\mathrm{N}$ release with photodissolution of SOM. This suggests that, as with $\mathrm{C}$, photodegradation speeds up $\mathrm{N}$ losses to the atmosphere and reduces $\mathrm{N}$ storage in litter and SOM.

\section{Effects on litter mass loss: a meta-analysis}

What factors across ecosystems influence the role photodegradation plays in litter decomposition? Field researchers have attempted to quantify the role of photodegradation in litter decomposition by manipulating the amount of solar radiation reaching the litter layer and measuring litter mass loss over time. Most field studies examine the effect of photodegradation in the presence of microbial decomposition (but see Austin and Vivanco 2006). The photodegradation effect is thus the difference in mass loss or decay rates between a control (e.g., that allows all radiation to pass through) and a treatment that either reduces solar radiation by filtering photodegradative wavelengths (UV-B, UV-A, and/or other wavelengths), blocking radiation completely, or increasing UV-BR using lamps. To examine the magnitude of solar radiation effects on mass loss (ML), we built a data set consisting of 50 field experiments drawn from 16 published, peer-reviewed sources (through July of 2011; see Appendix). We tested the influence of different treatment combinations, experimental 
approaches, initial lignin content, litter $\mathrm{C}$ to $\mathrm{N}$ ratio $(\mathrm{C} /$ $\mathrm{N}$ ) and litter area to mass ratio (area/mass) for the $\log$ response ratio for final mass loss (ML) of the higher solar radiation treatment compared to the lower solar radiation treatment for all studies $\left(\mathrm{LRR}_{\mathrm{enh}}\right.$, see Appendix for more details).

Effects of radiation treatment and experimental methods

Higher exposure of litter to solar radiation increased ML by $23 \%$ on average across all studies (Fig. 4a); however, results varied in relation to the type of experimental treatment. The experiments that compared enhanced UV-BR to reduced or ambient UV-BR found that increasing exposure had no effect on ML (95\% CI included zero), although these results may change with a larger sample size. Often, such experiments were designed to investigate the role of ozone depletion and the resulting increases in UV-BR on plant growth and litter chemistry, and thus only manipulated UV-B wavelengths by dosage changes projected to occur with ozone thinning. In these experiments, UV-BR-induced changes in litter quality also failed to impact photodegradation (95\% CI encompassed zero for litter produced under ambient, $N=10$, and enhanced, $N=4$, radiation; data not shown). In contrast, mass loss consistently increased in experiments that compared litter exposed to ambient versus reduced UV-BR, UV-A+BR, or total solar radiation $\left(32 \%\right.$ on average; $\mathrm{LRR}_{\mathrm{enh}}>1$; Fig. 4a). These experiments were more often designed specifically for testing the hypothesis that photodegradation played a role in litter mass loss in systems with high levels of radiation exposure and low moisture availability, and thus compared ambient controls to treatments that blocked a certain wavelength entirely.

Methods used to impose radiation treatments also affected the ML response, but it is difficult to tease apart the effect of method from the effect of experimental treatment (above). Enhancing litter exposure to UV-BR via supplementary lamps had no effect on ML ( $N=14,95 \%$ CI included zero; Fig. 4b). To date, no other methods have been used to increase the exposure of litter to UV-BR to examine effects on ML. Using shade cloths or filter treatments to reduce total solar radiation or UV radiation (UVR) reduced ML by 45 and $25 \%$, respectively $(n=11$ and 25 , respectively; Fig. 4b).

In studies that reduced solar radiation, reducing only UV-BR had the smallest effect on ML $(95 \%$ CI included zero; Fig. 4c). In contrast, blocking all solar radiation (via shade), radiation with wavelengths $<450 \mathrm{~nm}$, or UVA + BR all increased ML (Fig. 4c). Evidence to date suggests that short wavelength radiation in the visible range $(400-500 \mathrm{~nm})$ may substantially increase photodegradation (Fig. 4c; (a)

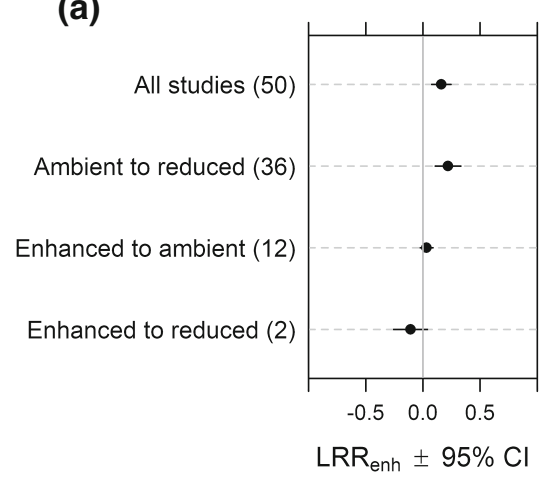

Fig. 4 Log response ratio for increasing the exposure of litter to solar radiation $\left(\mathrm{LRR}_{\mathrm{enh}}\right)$ in (a) all experiments and in experiments that increased the level of solar radiation (either UV-B, UV-A+B, or total) exposure: (i) from reduced solar radiation (via filters or shade) to ambient solar radiation, (ii) from ambient solar radiation to enhanced radiation (via lamps), and (iii) from reduced solar radiation to enhanced radiation, $\mathbf{b}$ by treatment type (lamp for enhanced radiation,

(b)

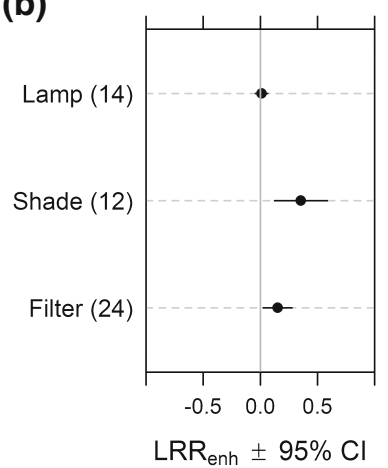

shade or filter for reduced radiation), and $\mathbf{c}$ by the amount and/or wavelengths of radiation blocked (total for shade, wavelengths of less than $450 \mathrm{~nm}$, UVA + UVB, or only UVB) in reduced experiments. Positive values indicate an increase in mass loss in response to increasing radiation. Negative values indicate reduced mass loss in response to increasing radiation. Sample sizes shown in parentheses 
Brandt et al. 2009). However, this study has yet to be replicated, so the magnitude of this effect is uncertain.

\section{Influence of radiation exposure}

The amount of radiation to which litter is exposed can be influenced by a variety of environmental factors including latitude, elevation, canopy cover and cloud cover, leading to increases or decreases in photodegradation rates (Table 1). It is difficult to tease apart the relative influence of these factors on photodegradation rates because the number of studies is limited, studies often use slightly different experimental approaches (see above), and many of these factors tend to co-vary. In general, our meta-analysis suggests that studies conducted at mid-latitude arid sites with low canopy cover demonstrate larger photodegradation effects compared to higher latitude sites, which could be due in part to greater radiation dosage at mid-latitude arid sites $\left(L R R_{\text {enh }}\right.$ decreased with increasing latitude in field experiments that compared ambient to reduced solar radiation; Fig 5a). This effect was independent of method (shade or filter) or wavelengths excluded (e.g., UV-B or UV-A + B; data not shown).

Not examined in the meta-analysis (due to lack of sufficient data) are the effects of other factors on radiation exposure (Table 1). For example, Brandt et al. (2010) conducted a field study comparing photodegradation rates in three contrasting grassland systems, hypothesizing that photodegradation rates should increase with decreasing latitude and increasing aridity. However, they found that factors such as seasonal monsoons and soil burial decreased the influence of photodegradation in the most arid site. Other studies have shown that burial by soil or additional litter can reduce exposure to radiation and thus reduce photodegradation rates (Henry et al. 2008; Throop and Archer 2009; Barnes et al. 2012).

\section{Influence of precipitation}

Our meta-analysis suggests that photodegradation plays the largest role in dry environments. With one exception, the $\mathrm{LRR}_{\text {enh }}$ decreased with mean annual precipitation (MAP; Fig. 5b). Precipitation data were only available for experiments that compared ambient to reduced solar radiation, so it is not known if this relationship would be significant for experiments that enhanced UV-BR. The exception to this trend was a single photodegradation study conducted in a Mediterranean climate (Henry et al. 2008). This site had both high MAP and photodegradation rates (Fig. 5b; Appendix). The large effect of increasing litter exposure to solar radiation was likely due to the highly seasonal nature of rainfall, which began several months after litter was placed in the field. This result suggests that MAP may not be a good predictor of photodegradation in climates with highly seasonal rainfall patterns. (a)

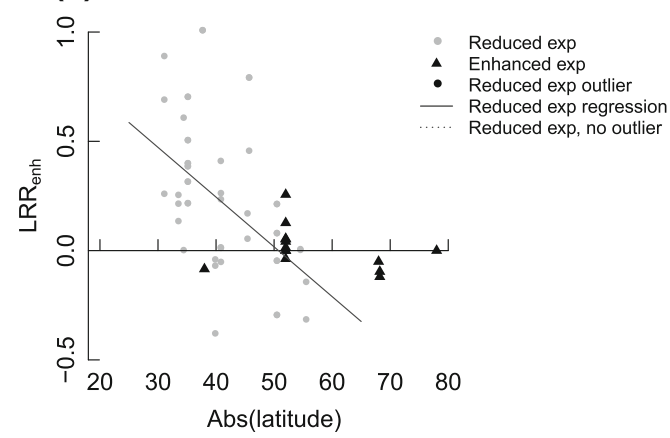

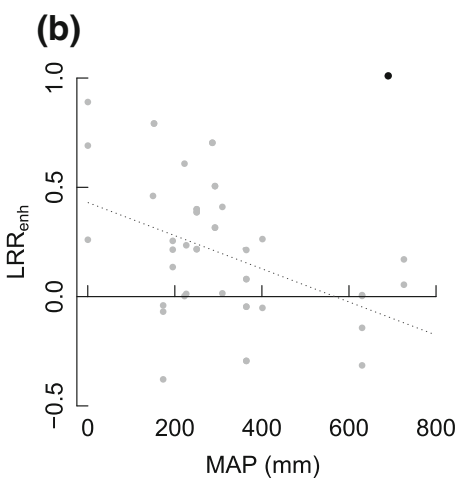

solar radiation experiments had MAP data available and so are the only experiments shown in the figure. A linear regression of all data versus MAP was not significant; removal of one outlier point (shown as a black circle; Henry et al. 2008) resulted in a significant relationship between $\mathrm{LRR}_{\mathrm{enh}}$ and MAP $(n=36$, $\left.\mathrm{LRR}_{\mathrm{enh}}=0.431-0.0008 \times \mathrm{MAP}, P=0.0041, r^{2}=0.224\right)$ 
A few studies have directly examined the influence of precipitation or moisture on the relative importance of photodegradation (Brandt et al. 2007; Gallo et al. 2009; Smith et al. 2010). These studies tested the hypothesis that under dry conditions, photodegradation should be more easily detectable, while under wet conditions microbial decomposition should dominate, not because photodegradation is reduced under wet conditions, but rather because microbial decomposition is reduced by dry conditions, making the photodegradation signal clearer. In addition, these studies hypothesized that under wet conditions, overall decomposition rates would decrease when litter is exposed to radiation because of negative impacts of UV-BR on the microbial community (Moody et al. 1999; Pancotto et al. 2003). In general, findings support these hypotheses (Brandt et al. 2007; Smith et al. 2010). However, one study conducted in a riparian forest in New Mexico did not find a precipitation effect, which the authors attributed to a low (15\%) difference between the precipitation treatment and control (Gallo et al. 2009). It is important to note that photochemical reactions could potentially be moisture-dependent (Schade et al. 1999) or could lead to increased litter solubility (Gallo et al. 2006), so actual photodegradation rates may be lower under dry conditions despite the fact that it accounts for a larger proportion of litter mass loss in dry versus mesic environments.

Influence of litter characteristics

Because lignin has been identified as a photosensitive compound (George et al. 2005), photodegradation is generally hypothesized to increase with lignin content (e.g. Moorhead and Callaghan 1994; Austin and Ballaré 2010). Instead, we found no relationship between $\mathrm{LRR}_{\text {enh }}$ and initial lignin content for experiments that compared ambient to reduced solar radiation, and $L_{R R}$ enh actually decreased with increased initial lignin content in experiments that compared enhanced UV to ambient or reduced UV treatments (Fig. 6a). The lack of relationship between $\mathrm{LRR}_{\text {enh }}$ and lignin content may be accurate, but it could also be a consequence of the narrow range of lignin contents used in reduced solar radiation experiments thus far (Fig. 6a; the one exception is Day et al. 2007 with a lignin content of $\sim 32 \%$ ). However, $\mathrm{LRR}_{\text {enh }}$ did increase with initial litter C/N (Fig. 6b).
An increase in litter $\mathrm{C} / \mathrm{N}$ can reduce microbial decomposition rates because of low $\mathrm{N}$ availability, thus increasing the proportion of decomposition that is due to photodegradation. $\mathrm{LRR}_{\mathrm{enh}}$ was also positively related to litter area/mass (Fig. 6c), a relationship that held across all reduced radiation experiments regardless of method or wavelengths excluded (data not shown; Appendix). This suggests an influence of litter density, presumably due to the shading of bottom litter layers from radiation by top layers in low area/mass experiments. Brandt et al. (2009) found support for this hypothesis by demonstrating that increasing litter density decreased photochemically-derived $\mathrm{CO}_{2}$ on a per unit mass basis, while $\mathrm{CO}_{2}$ released per unit area remained constant.

In addition to lignin content and litter density, other chemical and physical properties of litter could potentially influence photodegradation rates, but have not yet been examined. Studies in aquatic systems have shown that iron $\left(\mathrm{Fe}^{3+}\right)$ can play a large role in photodegradation of DOM (Gao and Zepp 1998); thus litter iron content may be an important factor. Other studies of DOM have shown that the degree to which DOM has been biodegraded can affect subsequent photodegradation rates and vice versa (Obernosterer and Benner 2004), so this may also hold true for litter. Other radiation-absorbing compounds such as flavonoids, tannins and anthocyanins may also influence photodegradation but have remained unexamined. Physical characteristics such as the presence of trichomes or cutin on the leaf surface may affect photodegradation rates by preventing radiation transmission. Many plants in arid environments have these characteristics to (at least in part) protect themselves from solar radiation, so these physical characteristics should be addressed when attempting to estimate photodegradation rates in arid systems.

\section{Methodological considerations}

Some of the variation in the meta-analysis results likely stems from the wide range of methods used to quantify litter photodegradation. Only a few studies have attempted to quantify photodegradation in the absence of microbial activity (Austin and Vivanco 2006; Brandt et al. 2009), and it is unclear whether the methods used may affect photodegradation measurements. Sterilization techniques such as autoclaving or gamma irradiation may change litter chemistry as it 
(a)

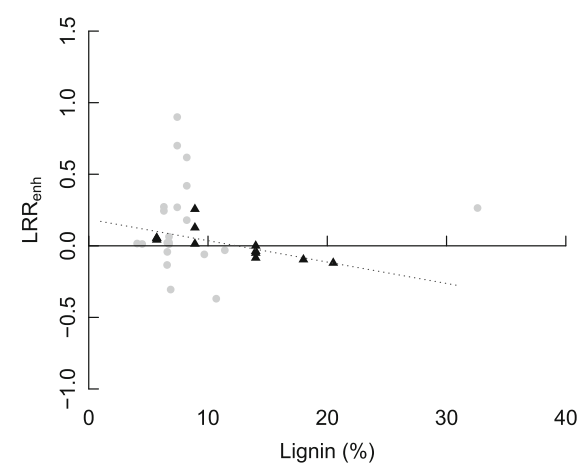

(c)

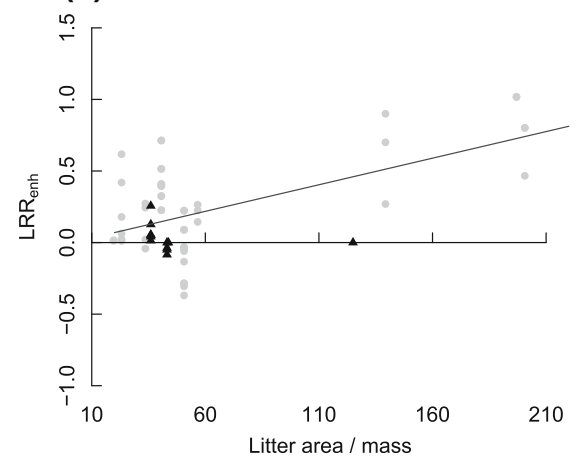

Fig. 6 a $\mathrm{LRR}_{\mathrm{enh}}$ by \% initial lignin content of litter. Linear regressions were only significant for enhanced UVR experiments $\left(n=14, \mathrm{LRR}_{\mathrm{enh}}=0.185-0.015 \times \%\right.$ lignin, $P=$ $0.0108, r^{2}=0.494$ ). Removal of one outlier point (from Day et al. 2007) did not result in significant regressions for either all or reduced solar radiation experiments. $\mathbf{b} \mathrm{LRR}_{\mathrm{enh}}$ by initial litter $\mathrm{C} / \mathrm{N}$. Linear regressions were significant for all experiments $\left(n=28, \quad \mathrm{LRR}_{\mathrm{enh}}=-0.125+0.004 \times \mathrm{C} / \mathrm{N}, \quad P=0.0001\right.$, $r^{2}=0.436$; regression not shown) and for reduced solar

does for SOM chemistry (e.g. Kelsey et al. 2010), and chemical biocides may interfere with or promote photochemical reactions in the litter (Katagi 2004). Finally, eliminating the microbial component may under- or overestimate the total contribution of photodegradation to decomposition by eliminating the potential positive or negative effects that photodegradation may have on subsequent microbial decomposition (Henry et al. 2008; Gallo et al. 2009; Foereid et al. 2010). Thus, most field studies have examined the effect of photodegradation in the presence of microbial decomposition by placing unaltered litter in the field.

Another factor that may contribute to variation among studies is the method used to contain litter. Many studies have used the standard litterbag (b)

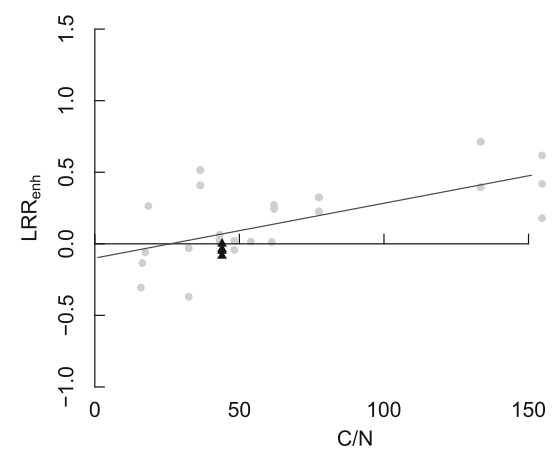

- Reduced exp

- Enhanced exp

- Reduced exp regression Enhanced exp regression

radiation experiments $\left(n=24, \mathrm{LRR}_{\mathrm{enh}}=-0.0998+0.004\right.$ $\left.\times \mathrm{C} / \mathrm{N}, P=0.0006, r^{2}=0.420\right)$. Note that there were not enough data points to calculate a regression for enhanced UV-BR experiments. c $\mathrm{LRR}_{\mathrm{enh}}$ by area/mass of litter. Linear regressions were significant for all experiments $(n=48$, $\mathrm{LRR}_{\text {enh }}=-0.031+0.004 \times$ area/mass, $\quad P<0.0001, \quad r^{2}=$ 0.309; regression not shown) and for reduced solar radiation experiments $\left(n=36, \mathrm{LRR}_{\mathrm{enh}}=-0.005+0.004 \times\right.$ area $/ \mathrm{mass}$, $\left.P=0.0002, r^{2}=0.337\right)$

technique with either supplementary UV-B lamps (Gehrke et al. 1995; Newsham et al. 1997; Moody et al. 2001), filters (Pancotto et al. 2003, 2005; Brandt et al. 2007, 2010), or shade cloths (Mackay et al. 1994; Köchy and Wilson 1997; Gallo et al. 2009) to manipulate the amount of radiation reaching the litterbag. The use of lamps or filters above traditional litterbags has the advantage of being directly comparable to other litterbag studies. This technique also has relatively minor effects on microclimate because filters and lamps are not in contact with the litter and can have perforations large enough to allow precipitation to reach the litter layer. In addition, filters and lamps can be replaced periodically to ensure consistent UV treatments. The disadvantage is that the mesh used in constructing litterbags covers a substantial 
proportion of the litter (50\% for fiberglass and $30 \%$ for aluminum), which leads to an underestimate of the effects of solar radiation (either positive or negative).

A few studies have constructed litter "boxes" or "packets" with clear UV-transparent or UV-blocking tops and bottoms made out of mesh or UV transparent material (Austin and Vivanco 2006; Day et al. 2007; Austin and Ballaré 2010), minimizing the problem of obstructing solar radiation. However, the UV-transparent materials themselves can photodegrade, thus altering their radiation transmission properties over time (Spartech Polycast, personal communication). The materials can also have significant effects on microclimate when placed directly above the litter, increasing temperature and decreasing the amount of precipitation reaching the litter. These factors could potentially lead to an overestimate of photodegradation rates if reaction rates are temperature-dependent or an underestimate of microbial decomposition processes due to low levels of water availability and very high temperatures. Since no method is without problems, we recommend that researchers fully disclose the limitations of their treatments to inform comparisons among studies.

\section{Modeling photodegradation}

Now that a basic understanding of the role of photodegradation in litter decomposition and $\mathrm{C}$ cycling is emerging, how can this information be incorporated into models of decomposition and biogeochemical cycling? Traditional decomposition models based on biotic drivers of decomposition (i.e., climate and litter chemistry) do not accurately predict decomposition in semi-arid and arid ecosystems (Meentemeyer 1978; Parton et al. 2007; see also Throop and Archer 2009), in some cases underpredicting long-term decomposition by as much as $25 \%$ (Adair et al. 2008). A primary candidate for explaining this discrepancy is photodegradation (Austin and Vivanco 2006; Adair et al. 2008; Vanderbilt et al. 2008). Despite this, photodegradation has yet to be adequately incorporated into terrestrial ecosystem models, a failure that is likely due to incomplete understanding of this process.

Large unanswered questions remain regarding the mechanisms driving photodegradation, substrate(s) and product(s) of photodegradation, and interactions of photodegradation with climate, local environmental conditions and biotic decomposition. Thus, the four existing terrestrial photodegradation models consist of exploratory exercises (Moorhead and Callaghan 1994; Rozema et al. 1999) or simple attempts to scale up CO production (Schade and Crutzen 1999) and mass loss (Foereid et al. 2011) rates. However, even these few modeling efforts have increased understanding of how photodegradation may fit into ecosystem functioning and large-scale C cycling. Moorhead and Callaghan (1994) modified the CENTURY ecosystem model to account for litter photodegradation by increasing the $\mathrm{C}$ transfer rate from structural litter to recalcitrant SOM and adding a $\mathrm{C}$ transfer from structural litter to labile SOM. These modifications increased litter turnover rates, but had little effect on SOM dynamics (Moorhead and Callaghan 1994). Another exploratory model allowed exposure to UV-BR to increase litter mass loss (all fractions) and increase the lignin content of litter inputs (due to exposure during growth; Rozema et al. 1999). While increasing UV-BR exposure did increase mass loss, UV-BR-induced lignin increases had larger negative effects on mass loss, resulting in slower mass loss rates regardless of UV exposure level (Rozema et al. 1999). However, while many studies have demonstrated that UVR exposure during growth affects plant tissue chemistry (see review in Caldwell et al. 2003), empirical studies have shown that the effects of UV-BR exposure during plant growth on decomposition may be minor or non-existent (e.g. Hoorens et al. 2004). Schade and Crutzen (1999) and Foereid et al. (2011) used models to scale up local photoproduction or photodegradation rates to global levels. Both estimated that photodegradation contributions to global fluxes of CO (Schade and Crutzen 1999) and litter mass loss (Foereid et al. 2011) were relatively small. Such models are useful at a coarse scale, but developing a model that fully accounts for the role of photodegradation in ecosystem function or the global $\mathrm{C}$ cycle requires greater understanding of the underlying mechanisms of photodegradation, its substrates and products, as well as its interactions with climate and microbial decomposition (Fig. 7).

A substantial challenge for modeling litter photodegradation lies in determining what is being photodegraded. Decomposition models often divide litter into different pools that decompose at different rates (e.g., fast, slow cellulosic and very slow lignin pools; 
Adair et al. 2008). If only lignin is photodegraded, incorporating photodegradation into traditional pool based models could significantly alter mass loss predictions (as in Moorhead and Callaghan 1994). Currently, there is substantial contradictory evidence as to whether (or how) photodegradation differentially affects various litter compounds or litter types (e.g., Brandt et al. 2009; Austin and Ballaré 2010). It is therefore unclear how to best represent litter mass loss in photodegradation models. While Moorhead and Callaghan (1994) assumed that only lignin was photodegraded, the remaining three studies modeled either litter mass losses without specifying which components were lost (Rozema et al. 1999; Foereid

(a)

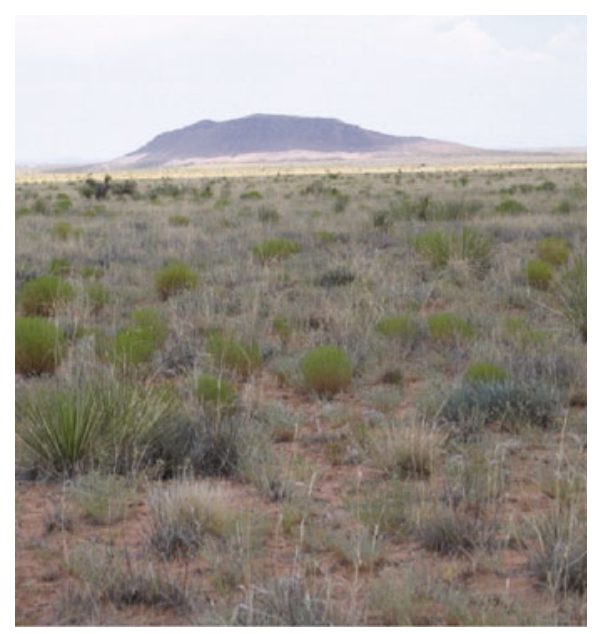

et al. 2011) or product formation without accounting for mass loss (Schade and Crutzen 1999).

If photodegradation affects all litter types similarly (if, e.g., mass loss is a function of surface area or there is a universal action spectrum for litter photodegradation), then differences in litter quality (e.g., lignin content) will not affect photodegradation rates. However, this seems unlikely given findings that DOM photodegradation rates and photoreactivity change with source and composition (e.g., Stubbins et al. 2011). Because the exact chemical structure of DOM is often unknown, DOM loss (or product formation) is often modeled via the development of "apparent" quantum yields (AQY; Miller et al. 2002). The AQY

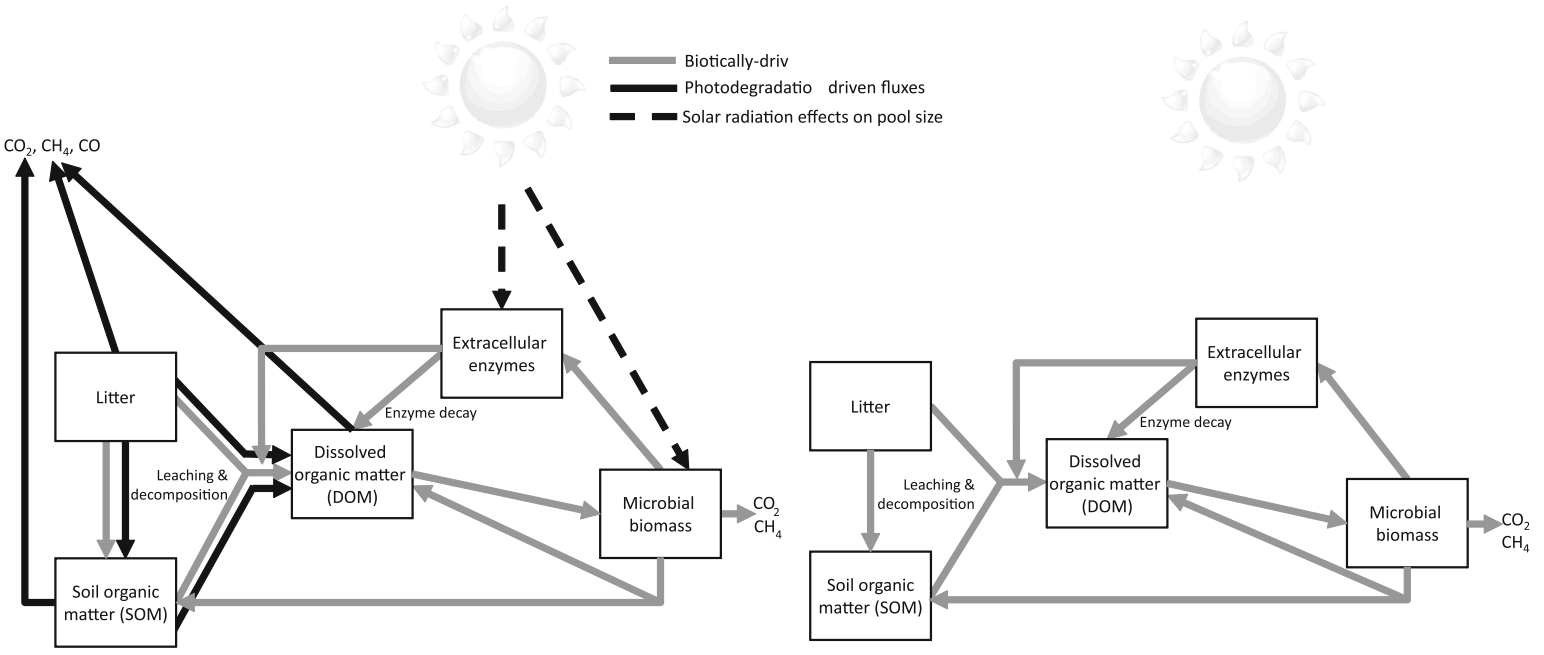

Fig. 7 Conceptual model of the differences in carbon cycling between a open canopy, arid systems and $\mathbf{b}$ relatively closed canopy, mesic systems. Both biotically-driven (gray) and photodegradation-driven (black) fluxes are shown. (Color figure online) 
describes the quantitative relationship between DOM breakdown (or photoproduct formation) and the amount of radiation absorbed by DOM (i.e., photoproduct amount per photon light absorbed). The AQY and DOM absorption are defined for individual wavelengths, and the product of AQY, DOM absorption and light availability is integrated across the wavelengths of interest to predict DOM disappearance (or photoproduct formation; e.g., Miller et al. 2002; Swan et al. 2009). Similar to aquatic systems, where the AQY and DOM absorption change with DOM source and composition (Stubbins et al. 2011), predicting photoproduct formation during terrestrial photodegradation may depend on plant litter photoreactivity changes with litter chemistry.

While some products of photodegradation are well known (e.g., $\mathrm{CO}_{2}, \mathrm{CH}_{4}, \mathrm{CO}$ ), not all of the relevant products have been identified. For example, there is little direct evidence of the conversion of litter to SOM by photodegradation (Mayer et al. 2012; Fig. 7), but it has been long hypothesized and was incorporated into Moorhead and Callaghan's (1994) photodegradation model. Even less is known about direct photodegradation of SOM or the contributions of photodegradation to soil $\mathrm{N}$ cycling, and no models currently address these processes.

As previously noted, solar radiation and photodegradation may interact with biotic decomposition by changing the biodegradability of litter or negatively impacting microbes (Fig. 7). Yet, none of the four terrestrial photodegradation models attempt to account for these interactions, likely because so little is known about them. Failing to account for these interactions will likely result in biased predictions of mass loss in systems exposed to high levels of solar radiation.

Developing a global photodegradation model requires understanding how photodegradation interacts with climate. We do not yet have a quantitative understanding of how litter moisture and temperature influence photodegradation rates and photoproduct yields. Results from aquatic systems suggest that photodegradation may be influenced by temperature; Zhang et al. (2006) found that the AQY of CO produced from DOM increased substantially with water temperature (by up to $70 \%$ between 0.5 and $32{ }^{\circ} \mathrm{C}$ ). Without understanding of how photodegradation processes change with temperature and moisture, attempts to scale up local photodegradation results to the globe will likely yield inaccurate estimates.

In contrast to models of aquatic systems (e.g., Miller et al. 2002), current terrestrial photodegradation models have been inconsistent in parameterizing litter exposure to solar radiation. Thus far, Rozema et al. (1999) took the most thorough approach: mass is lost linearly as a function of radiation exposure while accounting for light extinction through a canopy. Schade and Crutzen's (1999) model predicts global $\mathrm{CO}$ evolution from litter as a function of solar radiation, but does not explicitly account for light extinction (an "ecosystem factor" accounts for both light and litter availability). Similarly, Foereid et al. (2011) developed a linear equation that related mass loss to incident radiation, but their model did not account for light extinction. The Moorhead and Callaghan (1994) model did not use solar radiation as a model input. Basing photodegradation or photoproduct yield on the availability of solar radiation is an important first step. It remains to be determined whether it is necessary, as in aquatic models, to account for light extinction, canopy interception, substrate radiation absorption and photoproduct AQYs.

Whether terrestrial photodegradation will be best described by simple pool based models (e.g., Moorhead and Callaghan 1994) and/or linear equations (e.g., Foereid et al. 2011) or by more complex photochemical models (such as those developed for DOM) will only be known when the mechanisms driving terrestrial photodegradation are defined and sufficient data exist to conduct sophisticated model comparisons.

\section{Conclusions}

Research on the role of photodegradation in the decomposition of terrestrial plant litter over the past decade has fundamentally altered our perception of terrestrial $\mathrm{C}$ and $\mathrm{N}$ cycling as primarily biotic processes. Current estimates of $\mathrm{C}$ fluxes from photodegradation vary widely, but evidence suggests that a substantial fraction of net primary productivity can be returned to the atmosphere via this abiotic process, primarily as $\mathrm{CO}_{2}$. Research points to photodegradation as a source of other trace gases, including $\mathrm{CO}$, 
$\mathrm{CH}_{4}$, ethylene, and trace $\mathrm{N}$ gases. Some evidence also suggests that photodegradation may interact with biotic decomposition, potentially increasing microbial respiration rates by producing labile $\mathrm{C}$, but more studies are needed to better understand this interaction (Fig. 2).

Recent work and our meta-analysis show that photodegradation is most important in low latitude ecosystems and ecosystems characterized by low mean annual precipitation. However, photodegradation may also play an important role in climates with highly seasonal rainfall (e.g., Henry et al. 2008) or in mesic environments during very dry years (e.g., Brandt et al. 2010). Still, it is likely that photodegradation plays the largest role in arid and semi-arid ecosystems, where plant litter is highly exposed to solar radiation and where microbial decomposition may be limited by moisture and radiation conditions.

Rates of photodegradation are likely influenced by several factors, including temperature, moisture, litter chemistry and level of exposure to solar radiation. While research has revealed much about the climates where photodegradation is important, exactly how photodegradation interacts with changes in temperature and moisture remains unknown (Fig. 2). Our meta-analysis results indicate that photodegradation increases with litter $\mathrm{C} / \mathrm{N}$ and area/mass, but the effects of lignin content and litter chemistry in general are unclear. Much of this confusion likely originates from an incomplete understanding of the mechanisms driving terrestrial photodegradation.

A critical gap still exists in our understanding of the mechanisms by which photodegradation occurs. Thus far, most terrestrial photodegradation research has failed to differentiate between direct and indirect photochemical mechanisms. Research in aquatic systems and on wood and paper materials suggests that terrestrial ecologists should consider how these distinct mechanisms may differentially affect how litter is photodegraded. Working to better understand the mechanisms driving photodegradation will help us identify the important photo-active plant compounds, photodegradation products, and wavelengths, as well as allow us to improve models of $\mathrm{C}$ and $\mathrm{N}$ cycling in arid and semi-arid ecosystems.

Although many questions about photodegradation in terrestrial ecosystems have yet to be answered (Fig. 2), results to date indicate that, in arid and semiarid ecosystems, photodegradation speeds up $\mathrm{C}$ (and likely N) losses to the atmosphere and reduces storage in litter and SOM. The results of research on photodegradation patterns and mechanisms will continue to provide critical information for biogeochemical models and advancing understanding of ecosystem and global $\mathrm{C}$ and $\mathrm{N}$ cycling.

Acknowledgments Thanks to R. Sinsabaugh, S. Hobbie, D. Milchunas, and Y. Lin for their helpful comments on earlier versions of the manuscript. We appreciate the thorough and thoughtful comments provided by three anonymous reviewers. This work was supported by the National Science Foundation (NSF DEB 0542935 and 0935984).

\section{Appendix: Meta-analysis methods, data and references}

We conducted an extensive keyword and citation search using the ISI Web of Science for the words "photodegradation," "UV," "UV-B," "photolysis," and "solar radiation" in combination with "litter," "decomposition," and "organic matter." Within each reference, we collected information on the field site (latitude and mean annual precipitation, MAP), litter (species, initial lignin content, initial $\mathrm{C} / \mathrm{N}$, area/mass), treatment (supplementary lamp, filter, or shade cloth), experiment duration and the final mass loss (ML) in each treatment as a percentage of initial litter mass.

Many of the references we found contained research investigating photodegradation of different litter types, in different locations or by excluding or increasing different amounts/types of radiation, etc. Each of these was incorporated into the database as a single experiment. Thus, the database contained 16 references and 50 experiments (Table 3). For each experiment $(N=50)$ we calculated a metric that examined the effect of increasing litter UV exposure based on the log response ratio (LRR of enhancing solar radiation or $\left.\mathrm{LRR}_{\mathrm{enh}}\right): \mathrm{LRR}_{\mathrm{enh}}=\ln \left(\mathrm{ML}_{\mathrm{enh}} /\right.$ $\mathrm{ML}_{\text {red }}$ ), where $\mathrm{ML}_{\mathrm{enh}}$ is $\mathrm{ML}$ in the treatment with more solar radiation exposure and $\mathrm{ML}_{\mathrm{red}}$ is $\mathrm{ML}$ in the treatment with less UV exposure. $\mathrm{ML}_{\text {enh }}$ values $>0$ indicate that ML increases with increasing solar radiation exposure; values $<0$ indicate that $\mathrm{ML}$ decreases with increasing solar radiation exposure.

We examined $L_{R R}$ enh averaged across all experiments $(N=50)$ and by solar radiation treatment combinations. Across the 50 experiments, we examined three types of treatment combinations: 


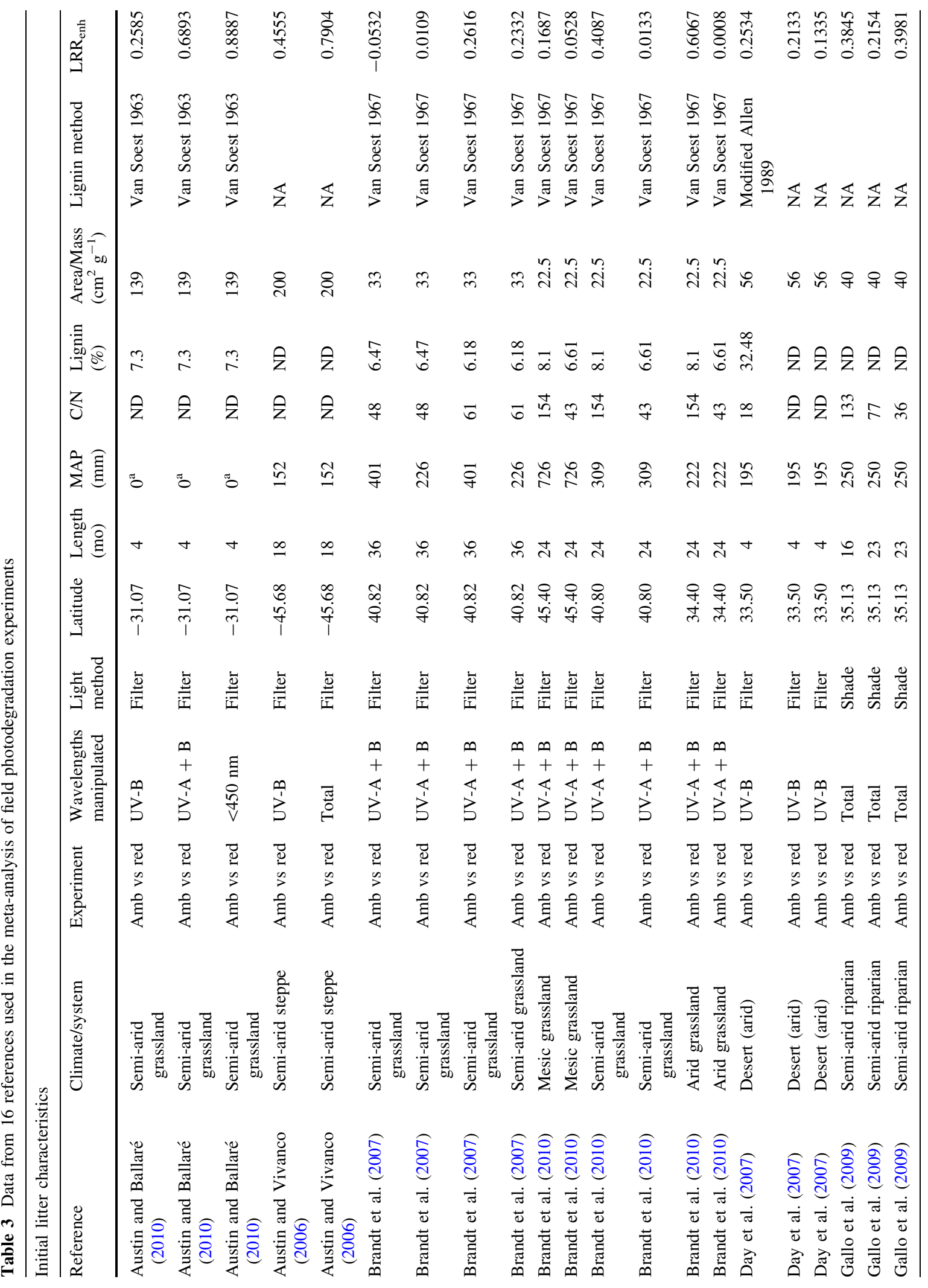




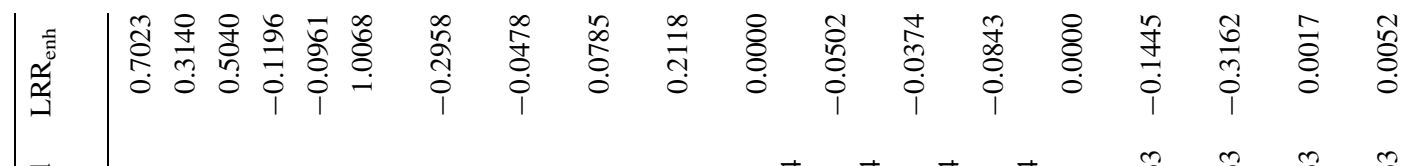

1)

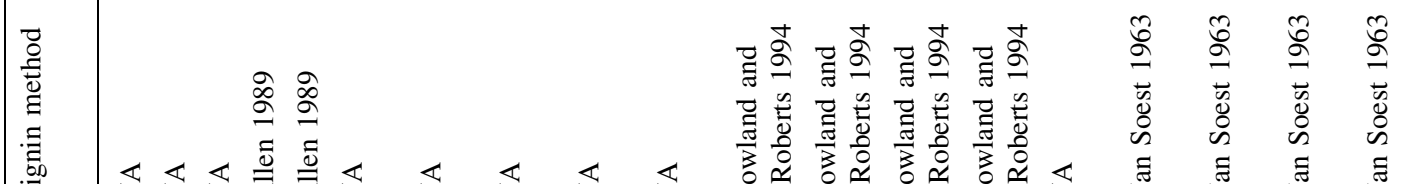

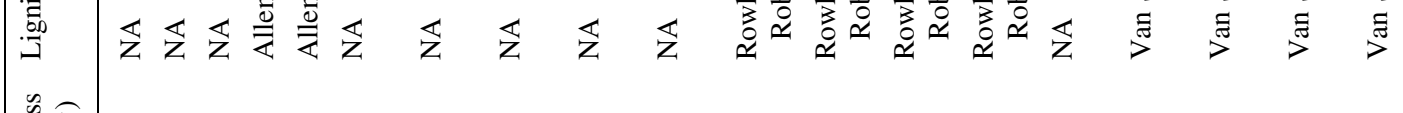

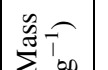

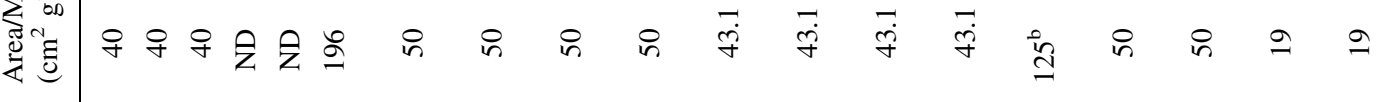

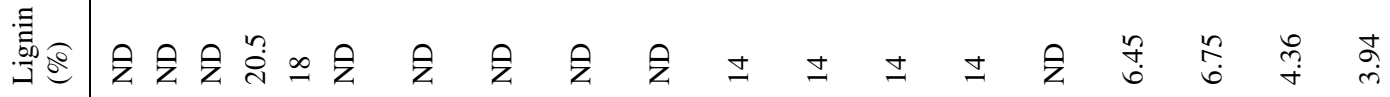

ż

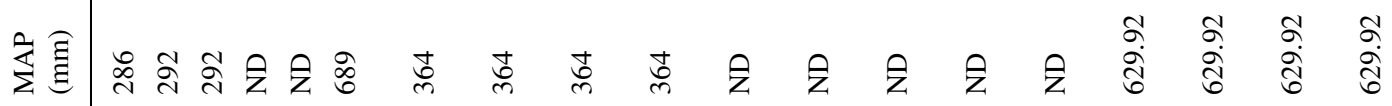

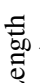

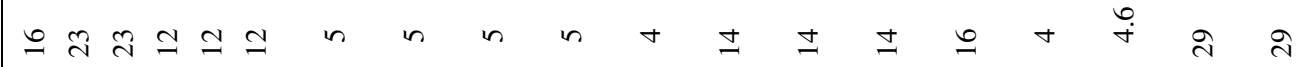

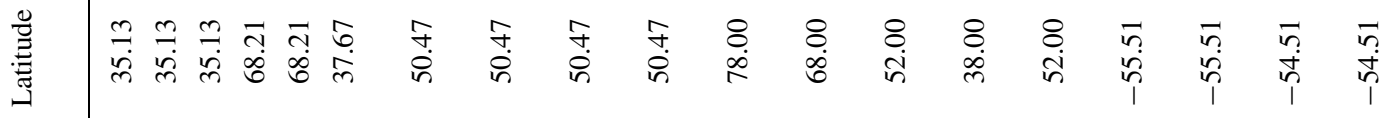

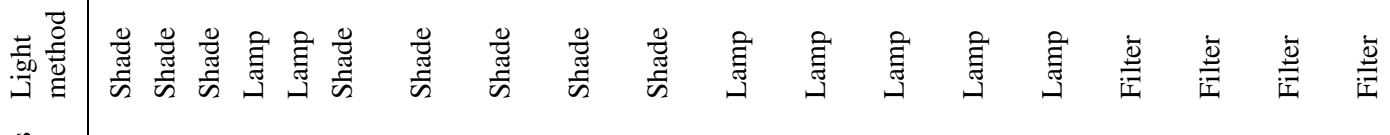
串兽

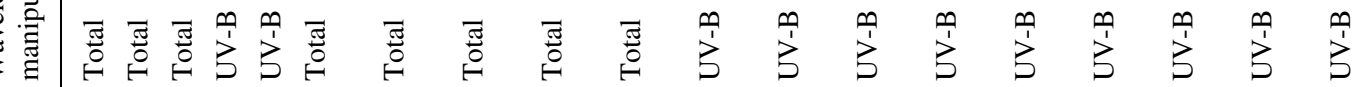

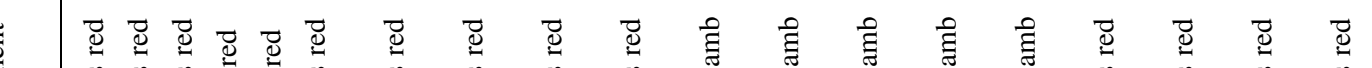

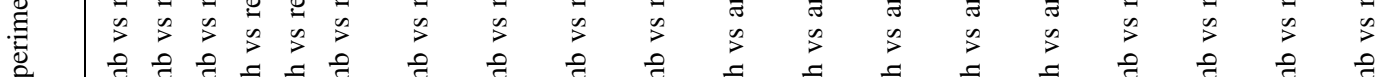

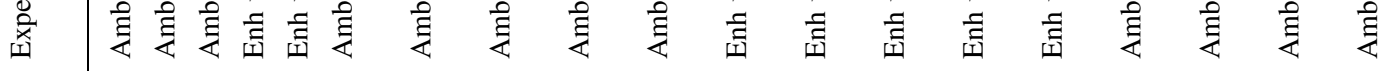

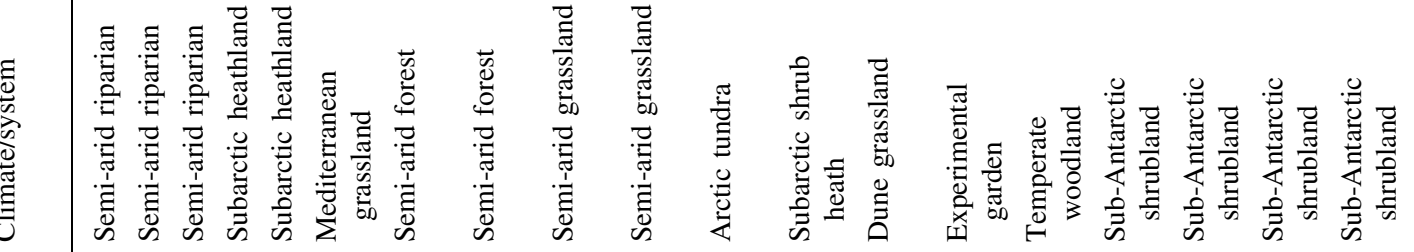

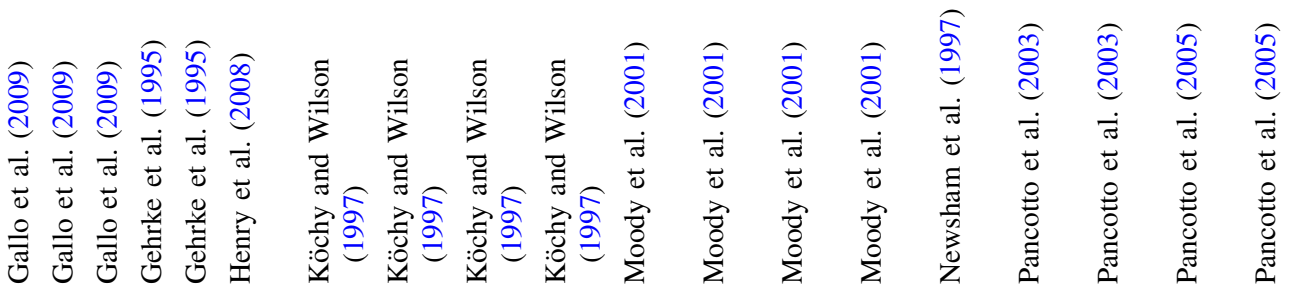




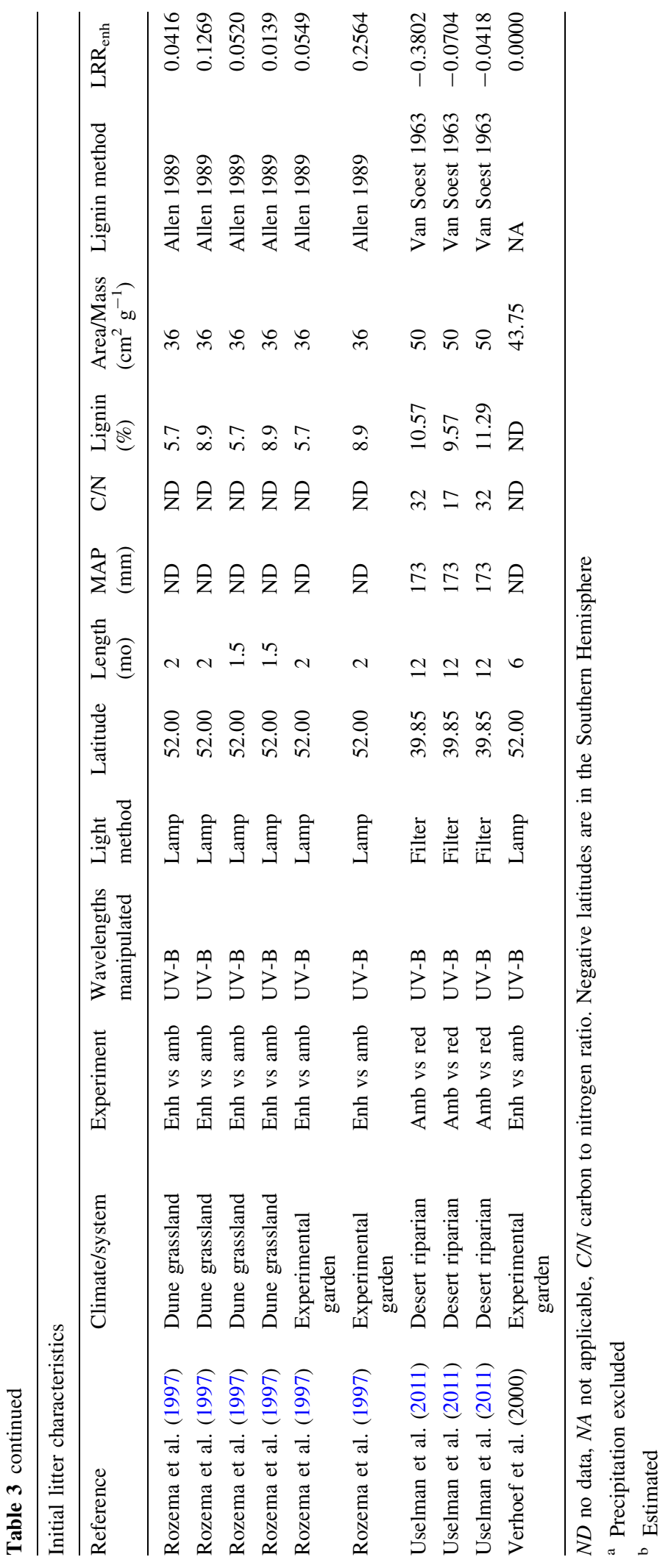


(1) enhanced versus ambient; (2) enhanced versus reduced; and (3) ambient versus reduced. Enhanced solar radiation treatments were accomplished via supplementary UV lamps, while reduced treatments used filters or shade cloths to block UVR and/or total solar radiation. We examined average $\mathrm{LRR}_{\mathrm{enh}}$ for each manipulation method (filter, supplementary lamp, or shade). For each mean $\mathrm{LRR}_{\text {enh }}$, we calculated a $95 \%$ confidence interval (CI; Student's $t$ distribution). Means were considered to be significantly different from zero if the $95 \%$ CIs did not include zero. We also examined linear relationships between experiment $\mathrm{LRR}_{\mathrm{enh}}$ and latitude, MAP, initial litter lignin content, initial litter $\mathrm{C} / \mathrm{N}$ and leaf litter area/mass.

Meta-analysis references:

Austin AT, Ballaré CL (2010) Dual role of lignin in plant litter decomposition in terrestrial ecosystems. Proc Natl Acad Sci USA 107 (10):4618-4622

Austin AT, Vivanco L (2006) Plant litter decomposition in a semi-arid ecosystem controlled by photodegradation. Nature 442 (7102):555-558

Brandt LA, King JY, Hobbie SE, Milchunas DG, Sinsabaugh RL (2010) The role of photodegradation in surface litter decomposition across a grassland ecosystem precipitation gradient. Ecosystems 13 (5):765-781

Brandt LA, King JY, Milchunas DG (2007) Effects of ultraviolet radiation on litter decomposition depend on precipitation and litter chemistry in a shortgrass steppe ecosystem. Glob Change Biol 13 (10):2193-2205

Day TA, Zhang ET, Ruhland CT (2007) Exposure to solar UV-B radiation accelerates mass and lignin loss of Larrea tridentata litter in the Sonoran Desert. Plant Ecol 193 (2):185-194

Gallo ME, Porras-Alfaro A, Odenbach KJ, Sinsabaugh RL (2009) Photoacceleration of plant litter decomposition in an arid environment. Soil Biol Biochem 41 (7):1433-1441

Gehrke C, Johanson U, Callaghan TV, Chadwick D, Robinson CH (1995) The impact of enhanced ultraviolet-B radiation on litter quality and decomposition processes in Vaccinium leaves from the sub-Arctic. Oikos 72 (2):213-222

Henry HAL, Brizgys K, Field CB (2008) Litter decomposition in a California annual grassland: interactions between photodegradation and litter layer thickness. Ecosystems 11 (4):545-554
Köchy M, Wilson SD (1997) Litter decomposition and nitrogen dynamics in aspen forest and mixedgrass prairie. Ecology 78 (3):732-739

Moody SA, Paul ND, Bjorn LO, Callaghan TV, Lee JA, Manetas Y, Rozema J, Gwynn-Jones D, Johanson U, Kyparissis A, Oudejans AMC (2001) The direct effects of UV-B radiation on Betula pubescens litter decomposing at four European field sites. Plant Ecol 154 (1-2):27-36

Newsham KK, McLeod AR, Roberts JD, Greenslade PD, Emmett BA (1997) Direct effects of elevated UV-B radiation on the decomposition of Quercus robur leaf litter. Oikos 79 (3):592-602

Pancotto VA, Sala OE, Cabello M, Lopez NI, Robson TM, Ballaré CL, Caldwell MM, Scopel AL (2003) Solar UV-B decreases decomposition in herbaceous plant litter in Tierra del Fuego, Argentina: potential role of an altered decomposer community. Glob Change Biol 9 (10):14651474

Pancotto VA, Sala OE, Robson TM, Caldwell MM, Scopel AL (2005) Direct and indirect effects of solar ultraviolet-B radiation on long-term decomposition. Glob Change Biol 11 (11):1982-1989

Rozema J, Tosserams M, Nelissen HJM, vanHeerwaarden L, Broekman RA, Flierman N (1997) Stratospheric ozone reduction and ecosystem processes: Enhanced UV-B radiation affects chemical quality and decomposition of leaves of the dune grassland species Calamagrostis epigeios. Plant Ecol 128 (1-2):284-294

Uselman SM, Snyder KA, Blank RR, Jones TJ (2011) UVB exposure does not accelerate rates of litter decomposition in a semi-arid riparian ecosystem. Soil Biol Biochem 43 (6):1254-1265

Verhoef HA, Verspagen JMH, Zoomer HR (2000) Direct and indirect effects of ultraviolet-B radiation on soil biota, decomposition and nutrient fluxes in dune grassland soil systems. Biol Fert Soils 31 (5):366-371

Lignin method references:

Allen, SE (1989) Chemical Analysis of Ecological Materials, 2nd edn, Chap 6. Blackwell Scientific Publications, London

Rowland AP, Roberts JD (1994) Lignin and cellulose fractionation in decomposition studies using acid-detergent fibre methods. Commun Soil Sci Plant Anal 25:269-277 
Van Soest PJ (1963) Use of detergents in the analysis of fibrous feeds. II. A rapid method for the determination of fiber and lignin. J Assoc Off Agric Chem 46:829-35

Van Soest PJ (1967) Development of a comprehensive system of feed analysis and its application to forages. J Anim Sci 26:119-128

\section{References}

Adair EC, Parton WJ, Del Grosso SJ, Silver WL, Harmon ME, Hall SA, Burke IC, Hart SC (2008) Simple three-pool model accurately describes patterns of long-term litter decomposition in diverse climates. Glob Change Biol 14(11):2636-2660

Amado AM, Cotner JB, Suhett AL, de Assis Esteves F, Bozelli RL, Farjalla VF (2007) Contrasting interactions mediate dissolved organic matter decomposition in tropical aquatic ecosystems. Aquat Microb Ecol 49(1):25-34

Anesio AM, Tranvik LJ, Graneli W (1999) Production of inorganic carbon from aquatic macrophytes by solar radiation. Ecology 80(6):1852-1859

Anesio AM, Graneli W, Aiken GR, Kieber DJ, Mopper K (2005) Effect of humic substance photodegradation on bacterial growth and respiration in lake water. Appl Environ Microb 71(10):6267-6275

Austin AT (2011) Has water limited our imagination for aridland biogeochemistry? Trends Ecol Evol 26(5):229-235

Austin AT, Ballaré CL (2010) Dual role of lignin in plant litter decomposition in terrestrial ecosystems. Proc Natl Acad Sci USA 107(10):4618-4622

Austin AT, Vivanco L (2006) Plant litter decomposition in a semi-arid ecosystem controlled by photodegradation. Nature 442(7102):555-558

Ballaré CL, Caldwell MM, Flint SD, Robinson A, Bornman JF (2011) Effects of solar ultraviolet radiation on terrestrial ecosystems: Patterns, mechanisms, and interactions with climate change. Photochem Photobiol Sci 10(2):226-241

Barnes PW, Throop HL, Hewins DB, Abbene ML, Archer SR (2012) Soil coverage reduces photodegradation and promotes the development of soil-microbial films on dryland leaf litter. Ecosystems 15:311-321. doi:10.1007/s10021011-9511-1

Belnap J, Phillips SL, Flint S, Money J, Caldwell M (2008) Global change and biological soil crusts: effects of ultraviolet augmentation under altered precipitation regimes and nitrogen additions. Glob Change Biol 14(3):670-686

Bloom AA, Lee-Taylor J, Madronich S, Messenger DJ, Palmer PI, Reay DS, McLeod AR (2010) Global methane emission estimates from ultraviolet irradiation of terrestrial plant foliage. New Phytol 187(2):417-425

Blumthaler M, Ambach W, Ellinger R (1997) Increase in solar UV radiation with altitude. J Photoch Photobio B 39(2): 130-134

Boreen AL, Edhlund BL, Cotner JB, McNeill K (2008) Indirect photodegradation of dissolved free amino acids: the contribution of singlet oxygen and the differential reactivity of DOM from various sources. Environ Sci Technol 42(15):5492-5498

Brandt LA, King JY, Milchunas DG (2007) Effects of ultraviolet radiation on litter decomposition depend on precipitation and litter chemistry in a shortgrass steppe ecosystem. Glob Change Biol 13(10):2193-2205

Brandt LA, Bohnet C, King JY (2009) Photochemically induced carbon dioxide production as a mechanism for carbon loss from plant litter in arid ecosystems. J Geophys Res-Biogeosci 114 (G02004). doi:10.1029/2008JG000772

Brandt LA, King JY, Hobbie SE, Milchunas DG, Sinsabaugh RL (2010) The role of photodegradation in surface litter decomposition across a grassland ecosystem precipitation gradient. Ecosystems 13(5):765-781

Bruhn D, Mikkelsen TN, Obro J, Willats WGT, Ambus P (2009) Effects of temperature, ultraviolet radiation and pectin methyl esterase on aerobic methane release from plant material. Plant Biol 11:43-48

Caldwell MM, Ballaré CL, Bornman JF, Flint SD, Björn LO, Teramura AH, Kulandaivelu G, Tevini M (2003) Terrestrial ecosystems, increased solar ultraviolet radiation and interactions with other climatic change factors. Photochem Photobiol Sci 2:29-38. doi:10.1039/b211159b

Cory RM, McNeill K, Cotner JP, Amado A, Purcell JM, Marshall AG (2010) Singlet oxygen in the coupled photochemical and biochemical oxidation of dissolved organic matter. Environ Sci Technol 44(10):3683-3689

Cramer W, Kicklighter DW, Bondeau A, Moore B, Churkina G, Nemry B, Ruimy A, Schloss AL (1999) Comparing global models of terrestrial net primary productivity (NPP): overview and key results. Glob Change Biol 5:1-15

Day TA, Zhang ET, Ruhland CT (2007) Exposure to solar UV-B radiation accelerates mass and lignin loss of Larrea tridentata litter in the Sonoran Desert. Plant Ecol 193(2): 185-194

Denward CMT, Tranvik LJ (1998) Effects of solar radiation on aquatic macrophyte litter decomposition. Oikos 82(1): $51-58$

Denward CMT, Anesio AM, Graneli W, Tranvik LJ (2001) Solar radiation effects on decomposition of macrophyte litter in a lake littoral. Arch Hydrobiol 152(1):69-80

Derendorp L, Holzinger R, Röckmann T (2011a) UV-induced emissions of $\mathrm{C}_{2}-\mathrm{C}_{5}$ hydrocarbons from leaf litter. Environ Chem 8:602-611

Derendorp L, Quist JB, Holzinger R, Röckmann T (2011b) Emissions of $\mathrm{H}_{2}$ and $\mathrm{CO}$ from leaf litter of Sequoiadendron giganteum, and their dependence on UV radiation and temperature. Atmos Environ 45:7520-7524

Duguay KJ, Klironomos JN (2000) Direct and indirect effects of enhanced UV-B radiation on the decomposing and competitive abilities of saprobic fungi. Appl Soil Ecol 14(2): 157-164

Feng XJ, Hills KM, Simpson AJ, Whalen JK, Simpson MJ (2011) The role of biodegradation and photo-oxidation in the transformation of terrigenous organic matter. Org Geochem 42(3):262-274

Foereid B, Bellarby J, Meier-Augenstein W, Kemp H (2010) Does light exposure make plant litter more degradable? Plant Soil 333(1-2):275-285 
Foereid B, Rivero MJ, Primo O, Ortiz I (2011) Modelling photodegradation in the global carbon cycle. Soil Biol Biochem 43(6):1383-1386

Gallo ME, Sinsabaugh RL, Cabaniss SE (2006) The role of ultraviolet radiation in litter decomposition in and ecosystems. Appl Soil Ecol 34(1):82-91

Gallo ME, Porras-Alfaro A, Odenbach KJ, Sinsabaugh RL (2009) Photoacceleration of plant litter decomposition in an arid environment. Soil Biol Biochem 41(7):1433-1441

Gao HZ, Zepp RG (1998) Factors influencing photoreactions of dissolved organic matter in a coastal river of the southeastern United States. Environ Sci Technol 32(19):29402946

Gehrke C, Johanson U, Callaghan TV, Chadwick D, Robinson CH (1995) The impact of enhanced ultraviolet-B radiation on litter quality and decomposition processes in Vaccinium leaves from the sub-Arctic. Oikos 72(2):213-222

George B, Suttie E, Merlin A, Deglise X (2005) Photodegradation and photo stabilisation of wood: the state of the art. Polym Degrad Stabil 88(2):268-274

Gholz HL, Wedin DA, Smitherman SM, Harmon ME, Parton WJ (2000) Long-term dynamics of pine and hardwood litter in contrasting environments: toward a global model of decomposition. Glob Change Biol 6(7):751-765

Henry HAL, Brizgys K, Field CB (2008) Litter decomposition in a California annual grassland: interactions between photodegradation and litter layer thickness. Ecosystems 11(4):545-554

Hernes PJ, Benner R (2003) Photochemical and microbial degradation of dissolved lignin phenols: implications for the fate of terrigenous dissolved organic matter in marine environments. J Geophys Res-Oceans 108 (C9). doi: 10.1029/2002JC001421

Hoorens B, Aerts R, Stroetenga M (2004) Elevated UV-B radiation has no effect on litter quality and decomposition of two dune grassland species: evidence from a long-term field experiment. Glob Change Biol 10(2):200-208

Johanson U, Gehrke C, Bjorn LO, Callaghan TV, Sonesson M (1995) The effects of enhanced UV-B radiation on a subarctic heath ecosystem. Ambio 24(2):106-112

Johnson D (2003) Response of terrestrial microorganisms to ultraviolet-B radiation in ecosystems. Res Microbiol 154(5):315-320

Johnson KA, Whitford WG (1975) Foraging ecology and relative importance of subterranean termites in Chihuahuan desert ecosystems. Environ Entomol 4(1):66-70

Katagi T (2004) Photodegradation of pesticides on plant and soil surfaces. Rev Environ Contam Toxicol 182:1-195

Kelsey JW, Slizovskiy IB, Peters RD, Melnick AM (2010) Sterilization affects soil organic matter chemistry and bioaccumulation of spiked $p, p^{\prime}$-DDE and anthracene by earthworms. Environ Pollut 158:2251-2257

Keppler F, Hamilton JTG, Brass M, Rockmann T (2006) Methane emissions from terrestrial plants under aerobic conditions. Nature 439(7073):187-191

Kieber RJ, Li A, Seaton PJ (1999) Production of nitrite from the photodegradation of dissolved organic matter in natural waters. Environ Sci Technol 33(7):993-998

Kirschbaum MUF, Lambie SM, Zhou H (2011) No UV enhancement of litter decomposition observed on dry samples under controlled laboratory conditions. Soil Biol Biochem 43(6):1300-1307

Kisselle KW, Zepp RG, Burke RA, Pinto AD, Bustamante MMC, Opsahl S, Varella RF, Viana LT (2002) Seasonal soil fluxes of carbon monoxide in burned and unburned Brazilian savannas. J Geophys Res-Atmos 107 (D20). doi: 10.1029/2001JD000638

Köchy M, Wilson SD (1997) Litter decomposition and nitrogen dynamics in aspen forest and mixed-grass prairie. Ecology 78(3):732-739

Lanzalunga O, Bietti M (2000) Photo- and radiation chemical induced degradation of lignin model compounds. J Photochem Photobiol, B 56(2-3):85-108

Lee H, Rahn T, Throop H (2012) An accounting of C-based trace gas release during abiotic plant litter degradation. Glob Change Biol 18:1185-1195

Ma S, Baldocchi DD, Hatala JA, Detto M, Yuste JC (2012) Are rain-induced ecosystem respiration pulses enhanced by legacies of antecedent photodegradation in semi-arid environments? Ag For Met 154-155:203-213

Mackay WP, Loring SJ, Zak JC, Silva SI, Fisher FM, Whitford WG (1994) Factors affecting loss in mass of creosotebush leaf-litter on the soil surface in the northern Chihuahuan Desert. Southw Natural 39(1):78-82

Madronich S, McKenzie RL, Björn LO, Caldwell MM (1998) Changes in biologically active ultraviolet radiation reaching the Earth's surface. J Photochem Photobiol, B 46(1-3):5-19

Mayer LM, Thornton KR, Schick LL, Jastrow JD, Harden JW (2012) Photodissolution of soil organic matter. Geoderma 170:314-321

McCalley CK, Sparks JP (2009) Abiotic gas formation drives nitrogen loss from a desert ecosystem. Science 326(5954): 837-840

McLeod AR, Fry SC, Loake GJ, Messenger DJ, Reay DS, Smith KA, Yun BW (2008) Ultraviolet radiation drives methane emissions from terrestrial plant pectins. New Phytol 180(1):124-132

Meentemeyer V (1978) Macroclimate and lignin control of litter decomposition rates. Ecology 59(3):465-472

Messenger DJ, McLeod AR, Fry SC (2009) The role of ultraviolet radiation, photosensitizers, reactive oxygen species and ester groups in mechanisms of methane formation from pectin. Plant, Cell Environ 32(1):1-9

Miller WL, Moran MA, Sheldon WM, Zepp RG, Opsahl S (2002) Determination of apparent quantum yield spectra for the formation of biologically labile photoproducts. Limnol Oceanogr 47(2):343-352

Mlambo D, Mwenje E (2010) Influence of Colophospermum mopane canopy cover on litter decomposition and nutrient dynamics in a semi-arid African savannah. Afr $\mathbf{J}$ Ecol 48(4):1021-1029

Moody SA, Newsham KK, Ayres PG, Paul ND (1999) Variation in the responses of litter and phylloplane fungi to UV-B radiation (290-315 nm). Mycol Res 103:1469-1477

Moody SA, Paul ND, Bjorn LO, Callaghan TV, Lee JA, Manetas Y, Rozema J, Gwynn-Jones D, Johanson U, Kyparissis A, Oudejans AMC (2001) The direct effects of UV-B radiation on Betula pubescens litter decomposing at four European field sites. Plant Ecol 154(1-2):27-36 
Moorhead DL, Callaghan T (1994) Effects of increasing ultraviolet-B radiation on decomposition and soil organicmatter dynamics: a synthesis and modeling study. Biol Fert Soils 18(1):19-26

Moorhead DL, Reynolds JF (1989) Mechanisms of surface litter mass-loss in the northern Chihuahuan Desert-a reinterpretation. J Arid Environ 16(2):157-163

Moorhead DL, Currie WS, Rastetter EB, Parton WJ, Harmon ME (1999) Climate and litter quality controls on decomposition: an analysis of modeling approaches. Glob Biogeochem Cycle 13(2):575-589

Moran MA, Zepp RG (1997) Role of photoreactions in the formation of biologically labile compounds from dissolved organic matter. Limnol Oceanogr 42(6):1307-1316

Nelson NB, Siegel DA, Carlson CA, Swan CM (2010) Tracing global biogeochemical cycles and meridional overturning circulation using chromophoric dissolved organic matter. Geophys Res Lett 37. doi:10.1029/2009g1042325

Newsham KK, McLeod AR, Roberts JD, Greenslade PD, Emmett BA (1997) Direct effects of elevated UV-B radiation on the decomposition of Quercus robur leaf litter. Oikos 79(3):592-602

Obernosterer I, Benner R (2004) Competition between biological and photochemical processes in the mineralization of dissolved organic carbon. Limnol Oceanogr 49(1):117124

Pancotto VA, Sala OE, Cabello M, Lopez NI, Robson TM, Ballaré CL, Caldwell MM, Scopel AL (2003) Solar UV-B decreases decomposition in herbaceous plant litter in Tierra del Fuego, Argentina: potential role of an altered decomposer community. Glob Change Biol 9(10):1465-1474

Pancotto VA, Sala OE, Robson TM, Caldwell MM, Scopel AL (2005) Direct and indirect effects of solar ultraviolet-B radiation on long-term decomposition. Glob Change Biol 11(11):1982-1989

Parton W, Silver WL, Burke IC, Grassens L, Harmon ME, Currie WS, King JY, Adair EC, Brandt LA, Hart SC, Fasth B (2007) Global-scale similarities in nitrogen release patterns during long-term decomposition. Science 315(5810): 361-364

Paul ND, Callaghan T, Moody SA, Gwynn-Jones D, Johanson U, Gehrke C (1999) UV-B impacts on decomposition and biogeochemical cycling. In: Rozema J (ed) Stratospheric ozone depletion: The effects of enhanced UV-B radiation on terrestrial ecosystems. Backhuys Publishers, Leiden, pp 117-133

Pauli F (1964) Soil fertility problem in arid and semi-arid lands. Nature 204(496):1286-1288

Rozema J, Tosserams M, Nelissen HJM, vanHeerwaarden L, Broekman RA, Flierman N (1997) Stratospheric ozone reduction and ecosystem processes: Enhanced UV-B radiation affects chemical quality and decomposition of leaves of the dune grassland species Calamagrostis epigeios. Plant Ecol 128(1-2):284-294

Rozema J, Kooi B, Broekman R, Kuijper L (1999) Modelling direct (photodegradation) and indirect (litter quality) effects of enhanced UV-B on litter decomposition. In: Rozema J (ed) Stratospheric ozone depletion: The effects of enhanced UV-B radiation on terrestrial ecosystems. Backhuys Publishers, Leiden, pp 135-157
Rutledge S, Campbell DI, Baldocchi D, Schipper LA (2010) Photodegradation leads to increased carbon dioxide losses from terrestrial organic matter. Glob Change Biol 16(11): 3065-3074

Schade GW, Crutzen PJ (1999) CO emissions from degrading plant matter (II). Estimate of a global source strength. Tellus Ser B-Chem Phys Meteorol 51(5):909-918

Schade GW, Hofmann RM, Crutzen PJ (1999) CO emissions from degrading plant matter (I). Measurements. Tellus Ser B-Chem Phys Meteorol 51(5):889-908

Smith WK, Gao W, Steltzer H, Wallenstein MD, Tree R (2010) Moisture availability influences the effect of ultraviolet-B radiation on leaf litter decomposition. Glob Change Biol 16(1):484-495

Stubbins A, Law CS, Uher G, Upstill-Goddard RC (2011) Carbon monoxide apparent quantum yields and photoproduction in the Tyne estuary. Biogeosciences 8(3):703-713. doi:105194/bg-8-703-2011

Swan CM, Siegel DA, Nelson NB, Carlson CA, Nasir E (2009) Biogeochemical and hydrographic controls on chromophoric dissolved organic matter distribution in the Pacific Ocean. Deep-Sea Res Pt I 56(12):2175-2192. doi: 101016/jdsr200909002

Tarr MA, Miller WL, Zepp RG (1995) Direct carbon-monoxide photoproduction from plant matter. J Geophys Res-Atmos 100(D6):11403-11413

Throop HL, Archer SR (2007) Interrelationships among shrub encroachment, land management, and litter decomposition in a semidesert grassland. Ecol App 17(6):1809-1823

Throop HL, Archer SR (2009) Resolving the dryland decomposition conundrum: Some new perspectives on potential drivers. Prog Bot 70:171-194. doi:101007/978-3-540-68 421-3

Tranvik LJ, Bertilsson S (2001) Contrasting effects of solar UV radiation on dissolved organic sources for bacterial growth. Ecol Lett 4(5):458-463

Uselman SM, Snyder KA, Blank RR, Jones TJ (2011) UVB exposure does not accelerate rates of litter decomposition in a semi-arid riparian ecosystem. Soil Biol Biochem 43(6): 1254-1265

Vahatalo A, Sondergaard M, Schluter L, Markager S (1998) Impact of solar radiation on the decomposition of detrital leaves of eelgrass Zostera marina. Mar Ecol-Prog Ser 170:107-117

Vanderbilt KL, White CS, Hopkins O, Craig JA (2008) Aboveground decomposition in arid environments: results of a long-term study in central New Mexico. J Arid Environ 72(5):696-709

Vigano I, van Weelden H, Holzinger R, Keppler F, McLeod A, Rockmann T (2008) Effect of UV radiation and temperature on the emission of methane from plant biomass and structural components. Biogeosciences 5(3):937-947

Vione D, Bagnus D, Maurino V, Minero C (2010) Quantification of singlet oxygen and hydroxyl radicals upon UV irradiation of surface water. Environ Chem Lett 8(2): 193-198

Whitford WG, Meentemeyer V, Seastedt TR, Cromack K Jr, Crossley DA Jr, Santos P, Todd RL, Waide JB (1981) Exceptions to the AET model: deserts and clear-cut forest. Ecology 62(1):275-277 
Whitford WG, Repass R, Parker LW, Elkins NZ (1982) Effects of initial litter accumulation and climate on litter disappearance in a desert ecosystem. Am Midl Nat 108(1): $105-110$

Zepp RG, Erickson DJ, Paul ND, Sulzberger B (2011) Effects of solar UV radiation and climate change on biogeochemical cycling: interactions and feedbacks. Photochem Photobiol Sci 10(2):261-279. doi:101039/C0pp90037k

Zhang Y, Xie HX, Chen GH (2006) Factors affecting the efficiency of carbon monoxide photoproduction in the St.
Lawrence estuarine system (Canada). Environ Sci Technol 40(24):7771-7777. doi:101021/Es0615268

Zlotin RI (1979) Destruction of the litter fall in forest steppe ecosystems: Animals, microrganisms, abiotic factors. In: Isakov YA (ed) Heterotrophs in ecosystems of central forest steppe. Institute of Geography, USSR Academy of Science, Moscow, pp 49-98 